\title{
THROWING ENGINES VERSUS GUNPOWDER ARTILLERY IN SIEGE ACTIVITIES IN THE MIDDLE AGES - AN EXAMPLE OF THE KINGDOMS OF POLAND AND BOHEMIA
}

\begin{abstract}
The invention of gunpowder and its use in projectile throwing is rightly regarded as one of the greatest, if not the greatest, innovations in the history of war technology. However, the first artillery, which we have some mention of in Europe in 1326, had to compete for a long time with various types of throwing engines used in military operations, especially sieges, successfully since ancient times. It was no different in Central Europe, where throwing engines were still used in siege in the $4^{\text {th }}$ quarter of the $15^{\text {th }}$ century. The article analyses written and archaeological sources confirming the simultaneous use of throwing engines and gunpowder artillery in the Kingdom of Poland and the Kingdom of Bohemia until the end of the $15^{\text {th }}$ century.
\end{abstract}

Keywords: Central Europe, Kingdom of Poland, Kingdom of Bohemia, Middle Ages, artillery, throwing engines

Received: 01.06.2020 Revised: 02.07.2020 Accepted: 05.07.2020

Citation: Strzyż P. 2020. Throwing Engines versus Gunpowder Artillery in Siege Activities in the Middle Ages - An Example of the Kingdoms of Poland and Bohemia. "Fasciculi Archaeologiae Historicae" 33, 103-123, DOI 10.23858/FAH33.2020.007

\section{Introduction}

In 1505 an atypical event in Prague was recorded in Staré letopisy české: "In this year, on Monday after St. Lawrence's day [11 August 1505], throwing engine shooting took place in Slovany. Lords from the Old and the New Town, town envoys, the bishop and the burgrave of Prague Lord of Hradec came to see this. Shooting was done across the river to the other bank and this was a rather unusual event'" ${ }^{1}$ What deserves to be underlined is that this event was unusual and it was not seen for long by the town's population. Therefore, why as early as in the early $16^{\text {th }}$ century did throwing engines which were once so popular become something like monsters from old legends? (Fig. 1).

In the $2^{\text {nd }}$ half of the $14^{\text {th }}$ century, there was a significant acceleration in economic, social and cultural

\footnotetext{
*Institute of Archaeology, University of Łódź, (D) https://orcid. org/0000-0001-6846-159X; piotr.strzyz@uni.lodz.pl

${ }^{1}$ Ze starých..., 291: Téhož roku w ponedeli po sv. Vavřince stříleli na Slovanech z praku. Přsišli se na to podivat staroměstši i novoměstši páni, poslové z měst, biskup i pražský purkrabi pan Hradecký. Střileli přes řeku na druhou stranu a bylo to něco nevídaného.
}

development in Central European countries. The Kingdom of Poland under the rule of Casimir III and the Kingdom of Bohemia under the Luxemburg dynasty, thanks to favourable political circumstances and economic recovery, began to quickly catch up with Western European countries in many fields of science and technology. One of the numerous manifestations of this phenomenon was the emergence and development of firearms. ${ }^{2}$ As it is known, the first mention of this phenomenon dates back to $1326 .{ }^{3}$ From Central European countries, this innovation reached the Teutonic Order in Prussia the fastest, as evidenced by information about the use of gunpowder artillery during the siege of Kaunas in 1362. ${ }^{4}$ For the territory of the Kingdom of Poland, this is the 1383 mention of the siege of Pyzdry artificem Barthosii lapidem aero de pixide in valvam civitatis jecisse, qui lapis duas clausuras valvae cum vehementia pertransiens. ${ }^{5}$ The siege of Bolesławiec on the Prosna

\footnotetext{
${ }^{2}$ Strzyż 2014, 5.

${ }^{3}$ DeVries and Smith 2012, 145-146.

${ }^{4}$ Johanns von Posilge, Chronik..., 81-82; Szymczak 2004, 12.

${ }^{5}$ Joannis de Czarnkow, Chronicon..., 726; Szymczak 2004, 14.
} 


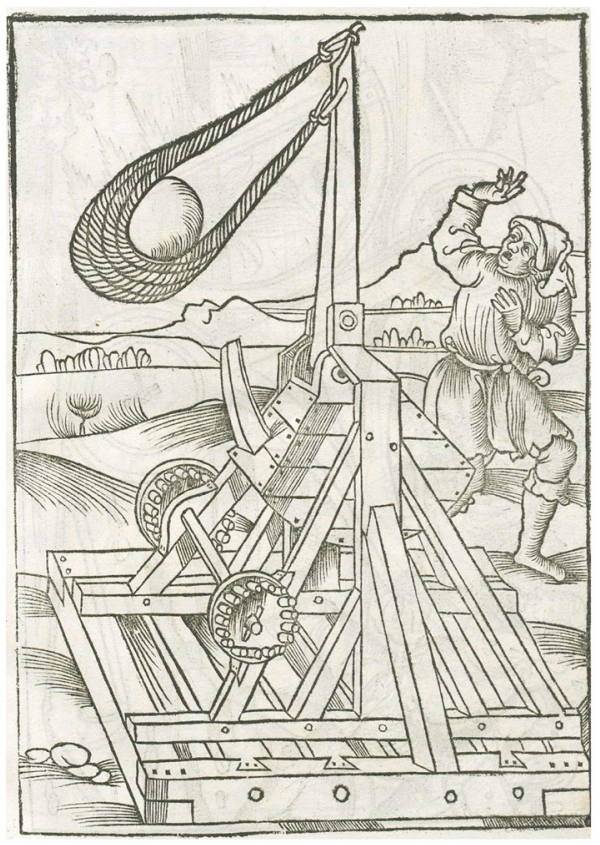

1

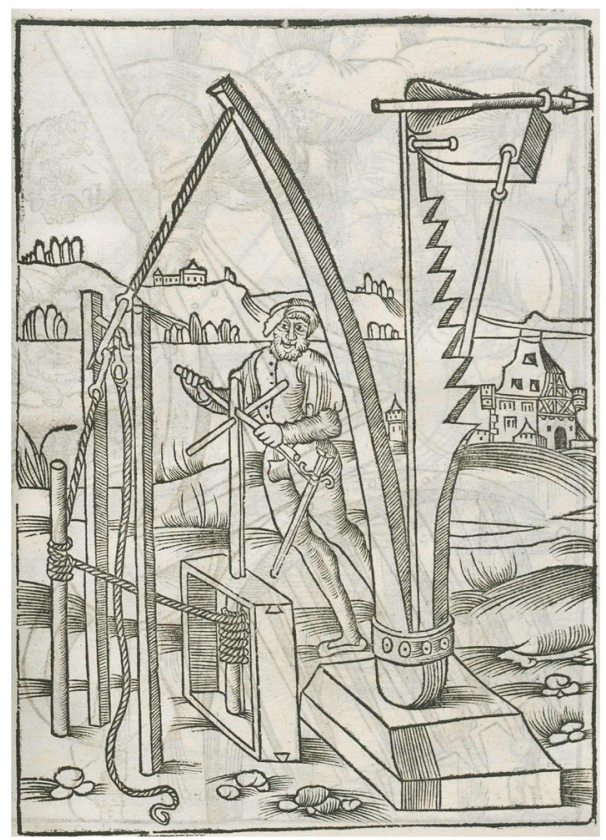

2

Fig. 1. Vegetius, De re militari, c. 1512: 1 - trebuchet, fol. XXI; 2 - bricole, fol. XCI.

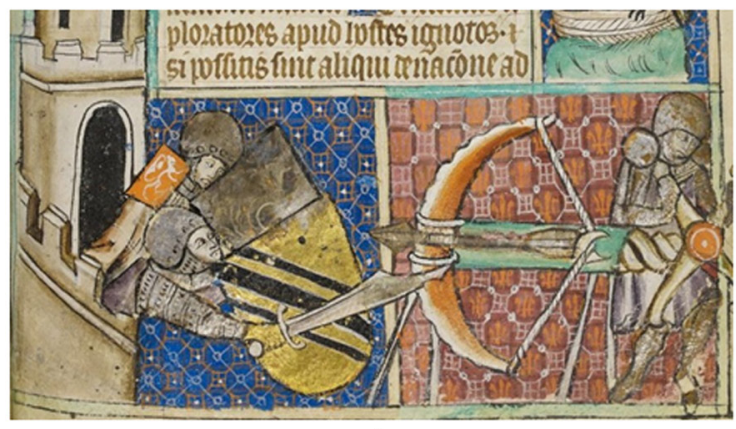

1

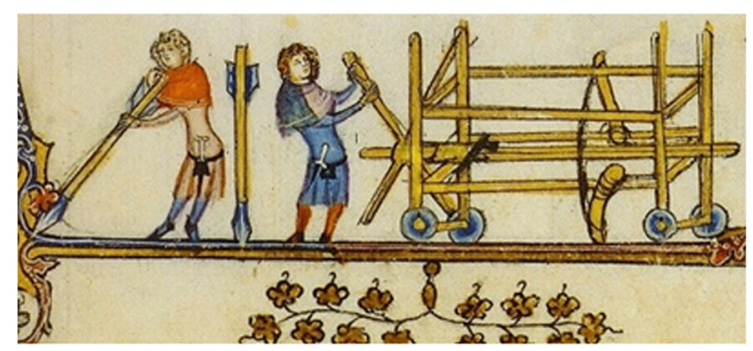

3

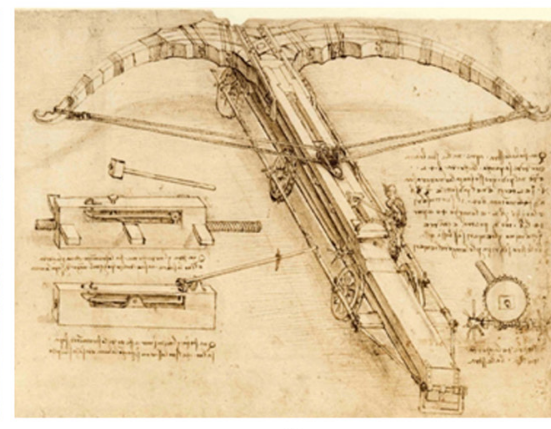

2

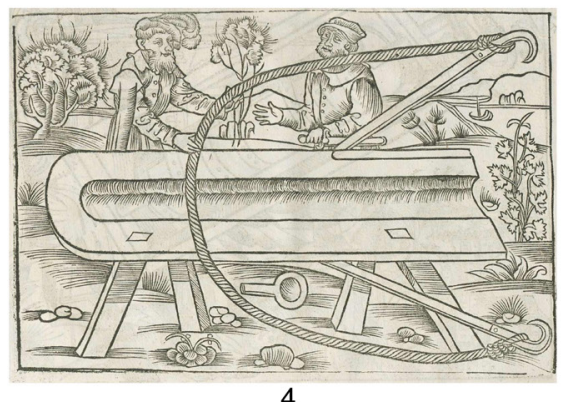

4

Fig. 2. Great crossbow: 1 - Walter de Milemete, De notabilitatibus, sapientiis et prudentiis regum, c. 1326, fol. 33. After Žákovský and Schenk 2017, Fig. 48; 2 - Leonardo da Vinci, Codice Atlantico, c. 1480, fol. 53v. Ballistae: 3 - Roman d'Alexandre,

c. 1338-1344, fol. 201. After Žákovský and Schenk 2017, Fig. 48; 4 - Vegetius, De re militari, c. 1512, fol. XVI.

in 1396 provided archaeologists with the oldest traces of the artillery siege site in Poland. ${ }^{6}$ The process of engaging firearms in military operations in the Kingdom of Bohemia was similarly dynamic. Already in 1373, the first canner was recorded in Prague, and in 1383 the first

${ }^{6}$ Szymczak 2005, 111-112; Strzyż 2014, 189-190, Fig. 24. fatal accident related to the use of quod pusska dicitur weapons was described. ${ }^{7}$ In 1399, due to the siege of the castle Skalá near Přeštice, pušku velikou was used. ${ }^{8}$

However, the new weapon was not perfect - it had poor accuracy with high failure rate and equally
${ }^{7}$ Život..., 467-468; Wagner et al. 1956, 82.
${ }^{8}$ Sedláček 1893, 174; Durdík 2009, 500. 


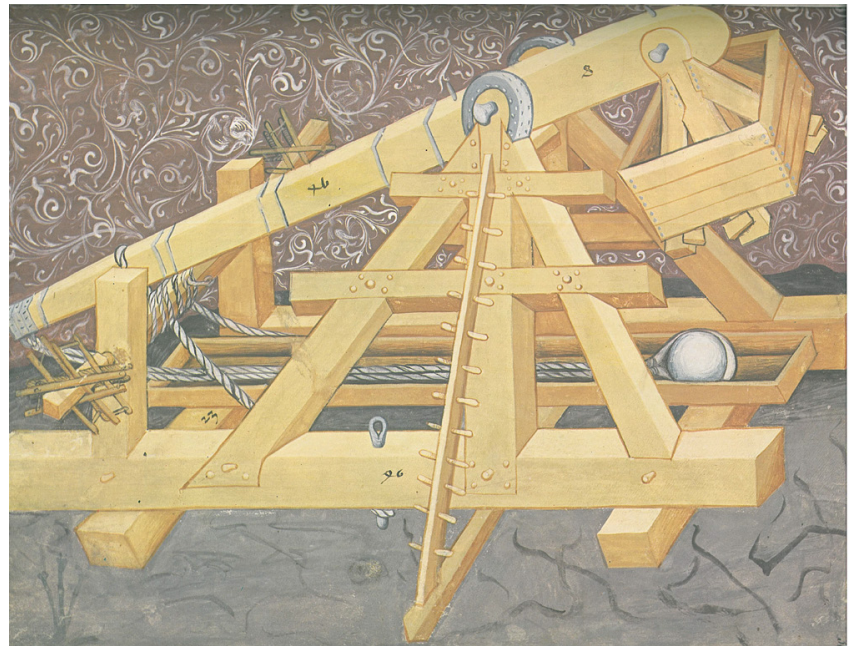

Fig. 3. Biffa. Kyeser, Bellifortis, fol. 30.

high cost of use. Therefore, for a very long time the throwing engines, with their centuries-old tradition of use, were simultaneously used in siege with artillery. These engines can be divided into two kinds. They could launch projectiles using the springiness of material or by employing energy which was accumulated in a counterweight raised to a considerable height. In the Middle Ages, the former included, among others, great crossbows, ballistae, bricoles or onagers. Their use in the Late Middle Ages is testified to by both written sources and iconography (Fig. 2:1-4). On the other hand, a great number of such throwing engines originated in Antiquity and in military traditions of the Roman Empire and even Greece. $^{9}$

The latter group include a broad and diversified range of machines which launched projectiles using a long arm and a counterweight. Depending on the counterweight's type, the following variants can be isolated: a trebuchet (immovable counterweight), a blida or biffa (movable counterweight) and a tripantium (with a double counterweight, a movable and immovable one). Furthermore, a so-called traction trebuchet was also in use, whose counterweight was lowered using the strength of human arms. These terminological suggestions are not always fully reflected in medieval nomenclature, where the most common terms are trebuchet and blida, no matter what counterweight was used. On the other hand, in Poland, Bohemia and in the Rus lands sources usually use such

${ }^{9}$ E.g.: Wagner et al. 1956, 79-80; Nowak 1965, 61-62; Szymczak 1979, 51-52; Jurga 1995, 8, 12, Tab. I: 5-10; Chevedden 1999, 134-164, Figs. 1-10; Klučina 2004, 138-139, 145-146; DeVries and Smith 2012, 126-130; Gravett 2018, 57-58. Due to the kind of employed energy, these are termed neuroballistic engines.

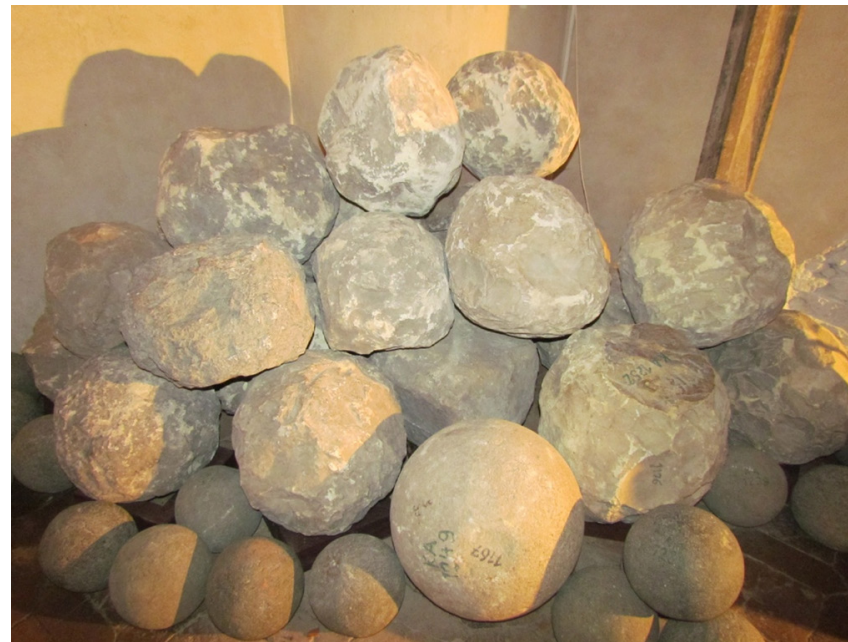

Fig 4. Cannon and throwing engine projectiles, Castle Karlštejn. Photo P. Strzyż.

terms as prak, prok or porok..$^{10}$ These machines were also depicted in iconographic sources from the period in question, including numerous military treatises (Fig. 3). Such engines were built both by specialist carpenters but also by any persons who were skilled in carpentry, like, e.g. a miller Hanko in the service of Duke Władysław the White. ${ }^{11}$

\section{The use of throwing engines in sieges in the territory of the Kingdom of Poland and the Kingdom of Bohemia in the $15^{\text {th }} \mathrm{c}$.}

The territories of the Kingdom of Poland and the Kingdom of Bohemia were also a theatre where some sort of contest between the 'old' and the 'new' was taking place for many years. It was long undecided which siege devices would prove better. The area in question yielded both numerous source mentions as well as material traces of their military coexistence.

There is no doubt that one of the most spectacular examples was the siege of Castle Karlštejn by joint Hussite forces and troops of Zygmunt Korybutowicz in 1422-1423. Pieces of information in sources provide good characteristics of the number of equipment in use and of its advantages and disadvantages.

In the Chronicle of Bartošek of Drahonic there is a general information: "In that year on Wednesday before St. Urban's day [20 May 1422] Prague troops with men of the mentioned voivode besieged the castle of

${ }^{10}$ E.g. Wagner et al. 1956, 80; Nowak 1965, 60-61; Szymczak 1979, 51-52; Jurga 1995, 8, 10, 44, Tab. I:1-4; Schmidtchen 2001, 311-314, Figs. 10 and 11; Klučina 2004, 138-145; DeVries and Smith 2012, 131-136; Gravett 2018, 59-61. Due to the kind of employed energy, these are termed baroballistic engines.

${ }^{11}$ Joannis de Czarnkow, Chronicon..., 659: Hanco molendinator Brestensis (...) quod in castro existens machinas et alia instrumenta exercitui regis in obsidione sui castri posito obviantia praeparasset; Cf. Głosek 1990, 154. 

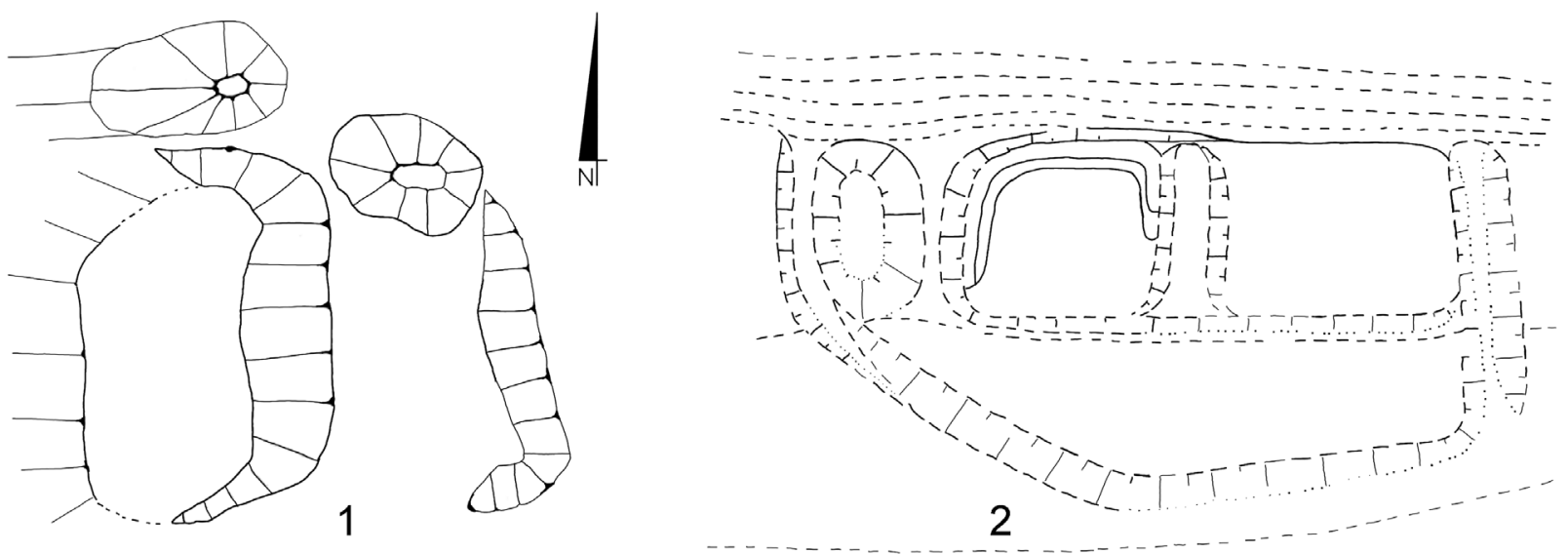

0 $10 \mathrm{~m}$

Fig. 5. Siege posts around Castle Karlštejn. 1 - Haknovec Hill; 2 - Javorka Hill. After Koscelník 2010, Figs. 3 and 4.

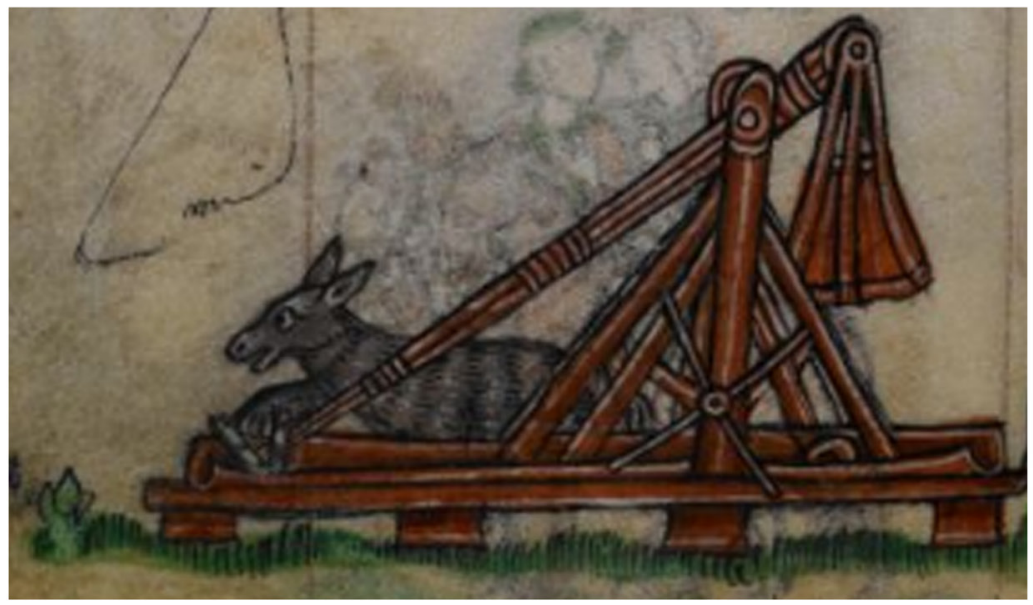

1

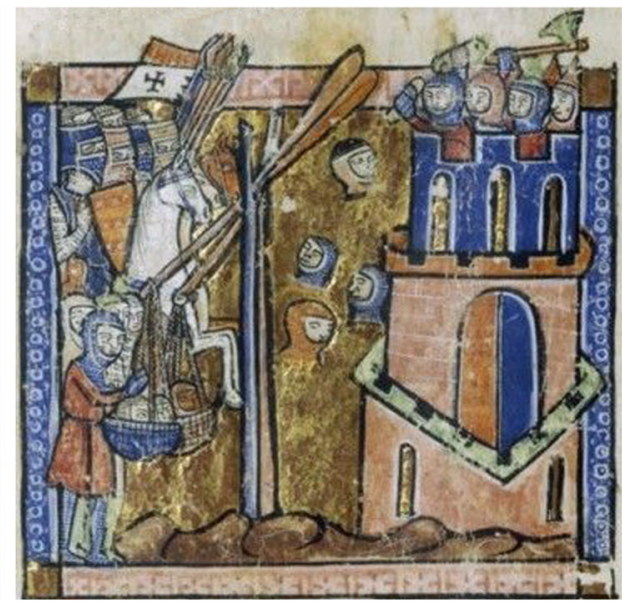

2

Fig. 6.1 - launching a dead horse using a trebuchet, The Book of Hours, $1^{\text {st }}$ quarter of the $14^{\text {th }}$ century, fol. 243v. After Serdon 2005, Fig. 15; 2 - throwing human heads with a trebuchet, William of Tyre, History of Outremer, c. 1250, fol. 22. After Gravett $2018,11$.

Karlštejn and strenuously attempted to take it by force with heavy cannons and five throwing engines". ${ }^{12}$

More detailed information was provided by Staré letopisy české: "In that year [1422] shortly thereafter, on Tuesday after the Pentecost [2 June] Duke Sigismund [Korybutowicz] with Prague troops and Poles besieged the castle of Karlštein. However, they did not capture it, although they attacked it with great strength and force and with throwing engines they threw many stinking barrels to the castle. (...) With throwing engines they threw 932 stones to the castle, apart from barrels with stinking refuse, which they carried from Prague, filled

${ }^{12}$ Bartošek z Drahonic, Kronika, 233; Bartossek de Drahonic, Chronicon, 592: Eodem anno Pragenses cum gentibus dicti ducis feria IV ante Urbani castrum Carlstein circumvallaverunt et dure cum magnis pixidibus et quinque machinie per potenciam lucrare nitebantur. with carcass and excrements. 822 such barrels were thrown with throwing engines. They fired seven times a day with the 'Pražka' cannon, seven times a day with the 'Jaromerka' and thirty times a day with the 'Rychlica' cannon, but they did not inflict any damage to the castle". ${ }^{13}$

Andreas of Regensburg, followed by Václav Hájek of Libočany, mentioned an exact location and equipment of individual siege posts: on the southern slope of

${ }^{13}$ Ze starých..., 90: Téhož roku brzy potom, v úterý o letnicich kniže Zikmunds Pražany a s Poláky oblehl hrad Karlštein, ale nedobyli jej, ačkoliv dobývali s velikou silou a mocí a z praku vrhali do hradu mnoho smrdutých sudu. (...) Do hradu vrhli z praku devět set dvaatřitcet kamenu a $k$ tomu ještě sudy se smrdutými nečistotami, které přiváželi mršinami a lejny naplněné z Prahy; těch sudu bylo z praku vrženo osm set dvacet dva. Z děla Pražky stř́leli sedmkrát denně, z Jaroměřky sedmkrát a z Rychlice třicetkrát za den, ale hradu nezpůsobili žádnou škodu. 


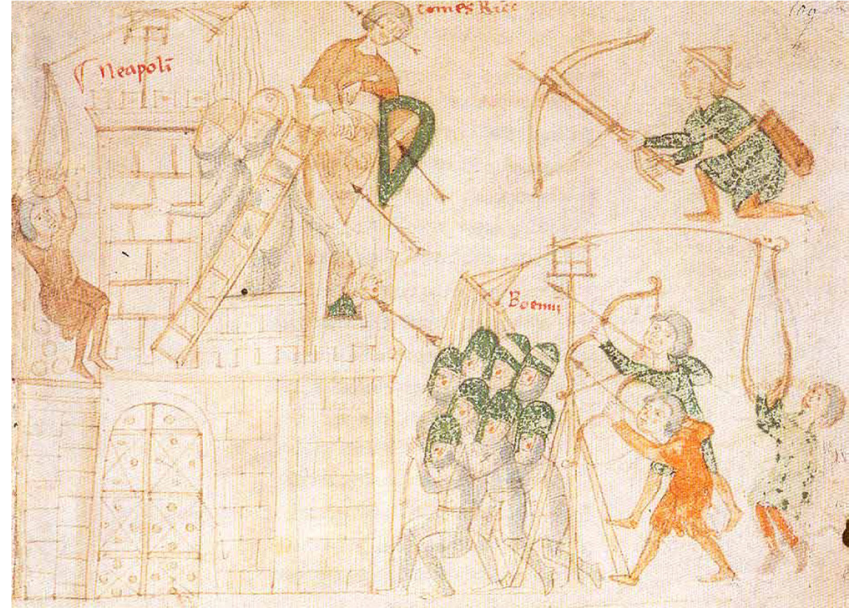

Fig. 7. Traction trebuchet used by Bohemian troops during the siege of Naples in 1191, Petrus de Ebulo, Liber ad honorem Augusti, c. 1195-1197, fol. 15a. After Gravett 2018, 8.

Kněža Hora there were two large cannons called Rychlica and Jaroměrka, 14 terrace-guns and one throwing engine from the Old Town of Prague. To the east of the castle, on Haknovec Hill, there was a bombard called Pražka, 12 terrace-guns and one throwing engine, also from the Old Town of Prague. Weapons deployed on Plešivec Hill included a cannon called Hovorka, 20 terrace-guns and a throwing engine from the Old Town of Prague. To the west of the castle on Javorka Hill there was a bombard called Trubačka, 8 terrace-guns and two throwing engines, one from the New Town of Prague and the other from Slany. It was believed that the castle was bombarded with 50-60 large calibre stone projectiles per day and their total number was 932 (Fig. 4). Prague troops also brought from the capital town pieces of stonework from the partially destroyed Church of Our Lady of the Snows. These were launched at the castle using throwing engines. ${ }^{14}$

What is more, Václav Hájek of Libočany mentions a report on excrements being projected at the castle and countermeasures undertaken by defenders: "They were throwing numerous and stinking carcasses into the castle. They were taking excrements from latrines in Prague, were transporting them there and were throwing then in vessels into the castle in order to stink out the defenders. However, the defenders had a lot of unslaked lime and many barrels of arsenic oxide. They poured these out on these stinking things; however, due to enormous stench, teeth of some defenders fell out or were moving". ${ }^{15}$ However,

${ }^{14}$ Sedláček 1889, 47-48; Menclová 1972, 218-219; Hájek, Kronika..., 926.

${ }^{15}$ Hájek, Kronika..., 927: Mrchy rozličné a smrduté jím tam do hradu házeli, nečistoty berouce z záchodìv z Prahy, tam je vozili a v soudcich z prakův do zámku házeli, chtice je vysmraditi. this author gives a higher total number of projectiles of all kinds that were launched: "Each day, they fired the 'Pražka' six times, the 'Jaromiřica' - six times, the 'Hovorka' - six times, the 'Trubačka' - six times, and the 'Rychlica' many times more. They fired other smaller cannons very frequently, and all this was done with stone cannonballs, which did minor damage. Many stones were launched with throwing engines. 1822 vessels with carcasses and other stinking things were thrown, and only 13 fire vessels were launched. Using large and small cannons and throwing engines they inflicted 10,931 wounds and damages, but they did not obtain anything". ${ }^{16}$ Military operations at Castle Karlštejn confirm advantages of throwing engines. Apart from ordinary stone projectiles, such engines were able to launch stonework from churches, barrels with excrements and flammable materials, as well as carcasses, which could not be done with artillery. What is more, it seems that sources indicate a higher rate of fire of throwing engines as compared with that of bombards. Furthermore, according to some reports, the latter became destroyed.

A partial confirmation of pieces of information from written sources was acquired with the use of archaeological non-invasive methods. Two posts of throwing engines were recorded on hills surrounding the castle. On Haknovec Hill there was a double post with dimensions of $12 \times 8 \mathrm{~m}$ and $17 \times 8 \mathrm{~m}$ respectively. Near each site there was a small earthwork, which may have been remains of soil that was used for filling the chest of the engine's counterweight (Fig. 5:1). After the siege had ended and the device was dismantled, the soil was thrown away onto the ground. Another feature was identified on Javorka Hill. Its dimensions are $12 \times 8 \mathrm{~m}$. It was accompanied with a $8 \times 8 \mathrm{~m}$ terrace, separated with a cut and surrounded with a rampart on the western side (Fig. 5:2). Perhaps in this place there was a shelter for the engine's crew. Additionally, the entire post was surrounded with an additional cut (moat) on the east, south and west. ${ }^{17}$ If this interpretation is correct, there is some contradiction with

Ale oni na zámku měli mnoho vápna nehašenéha a mnoho tun hutrejchu a tím na ty smrady sypali, v̌̌ak proto pro veliký smrad některým zuby vypadaly a jiným se hejbaly. See also Jana Długosza, Roczniki..., ks. 11 i 12, 175.

${ }^{16}$ Hájek, Kronika..., 928: každý den z Pražký šestkrát střelili, z Jaromiřice šestkrát, z Hovorky šestkrát, z Trubačky šestkrát, $z$ Rychlice pak mnohém častěji a z jiných menšich velmi často a to všecko kulemi kamennemi, kterýmiž malou škodu učinili. Z prakův také mnoho kamenưv vházeli, soudkův s mrchami, a s jinými smrady tisic osm set dvacet a dva tam uvrhli, soudkưv ohnivých toliko třináct a tak $z$ děl velikých i malých, také $i$ z prakưv udělali ran a hození deset tisíc devět set třicet a jednu, však proto nic nedobyli. See also Koscelník 2010, 89 - 9022 stones, 22 fire barrels and 1822 barrels with excrements are mentioned there.

${ }^{17}$ Koscelník 2010, 91-92, Figs. 3 and 4. 


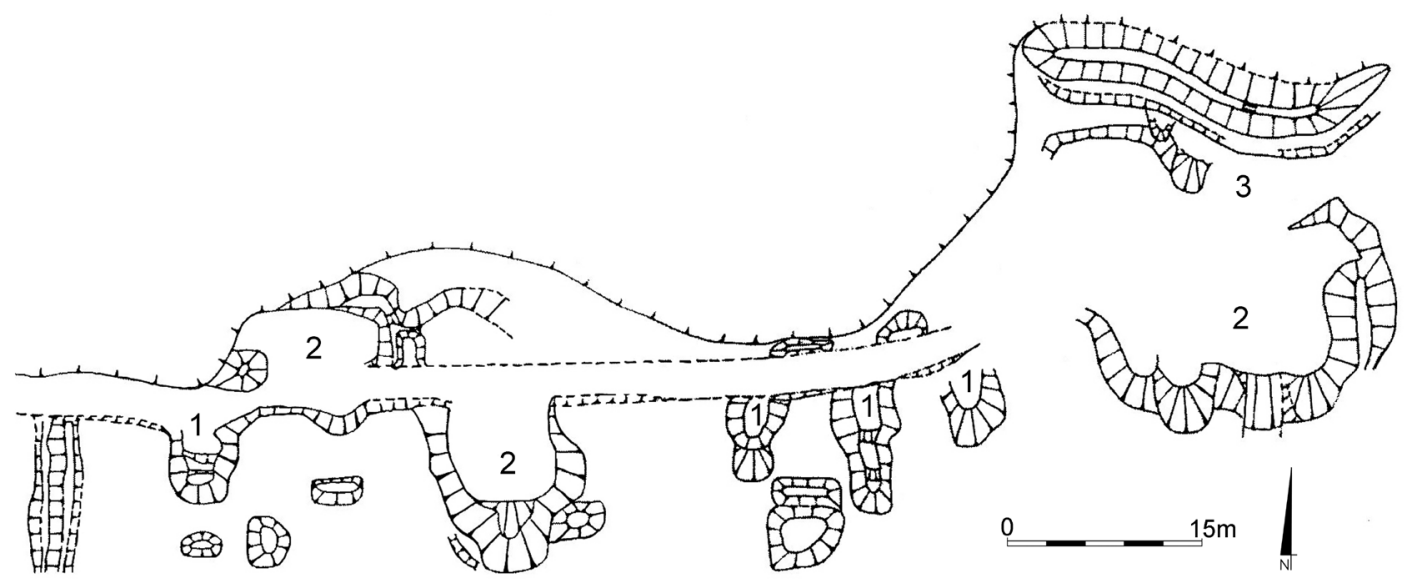

Fig. 8. Bechyně - fire position. 1 - bombard, 2 - trebuchet; 3 - terrace protected the eastern shooting line. After Kypta and Richterová 2004, Fig. 6.

written sources, as only one trebuchet was mentioned on Haknovec Hill, while two were reported on Javorka Hill.

A similar tactics was employed by Polish troops during the siege of Łuck in 1431. According to Jan Długosz, the basic siege force was: "Large cannons, which were also moved close to the castle, fired at the wall, destroyed it and demolished numerous towers and a considerable part of the wall. It was in spite of the fact that King Władysław reprimanded the destruction of walls and admonished some men to refrain from firing cannons". In result of heavy bombardment "fortifications were scattered and empty, and the wall was pulled down in many places". ${ }^{18}$ In spite of this, however, various political intrigues did not allow the Polish forces to fully exploit the effectiveness of cannons that were used. Therefore, "On Saturday, on St. Giles' day [1 November 1431], a masterfully constructed throwing engine [prok] that was built from timber logs and was deployed on the other side of the River Styr, provoked great fear among the castle's garrison as a new and unusual thing. This was because stones it launched were of amazing size and they hit many mortals. Furthermore, similar fear was provoked among many by horse carcasses that were thrown into the castle". ${ }^{19}$ Also in this case the role of throwing engines is quite significant and it was not solely limited

${ }^{18}$ Jana Długosza Roczniki..., ks. 11 i 12, 39, 40; Joannis Dlugossii Annales..., liber XI et XII, 31-32: Bombarde quoque maiores castro admote, quaciebant et rumpebant murum et plures turres et spacium notabile muri disiecerant, Wladislao rege improbante murorum concusionnem et exhortante aliquos, ut a proieccione bombardarum abstineretur (...) menibus disiectis et nudatis muroque in frequentibus locis dispupto (...).

${ }^{19}$ Jana Długosza Roczniki..., ks. 11 i 12, 46; Joannis Dlugossii Annales..., liber XI et XII, 37: Sabato, in die sancti Egidii, prok ex lignis magistraliter et artificiose dispositus et ex altera parte fluminis Stir locatus, magnum castrensibus velut res nova et insolita attulerat pavorem, cum et lapides mire magnitudinis ex illo proiecti multos mortales offenderent et cadavera quorum in castrum similiter proiecta multos turbarent. to launching of stone projectiles, as horse carcasses were also thrown into the castle. What is also important is that the raw material from which this prok was constructed, i.e., timber logs, was mentioned.

Examples of throwing of alternative projectiles are also provided by other source records. In 1332 Teutonic troops besieged the stronghold in Brześć Kujawski (PL). What was thrown behind the ramparts were not only stone projectiles but also pots with tar and ignited torches in order to set fire to buildings. ${ }^{20}$ In the course of siege of Boskovice (CZ) by Brno troops in 1389 barrels with excrements were thrown at defenders. ${ }^{21}$ Furthermore, during the siege of Schwanau (DE) in 1332 by Strasbourg troops, besiegers used trebuchets for throwing barrels with quartered bodies of 48 prisoners, including three carpenters, into the town. ${ }^{22}$ The fact that the aforementioned proceedings were commonplace is also demonstrated by medieval iconography (Fig. 6).

A parallel use of throwing engines and gunpowder artillery is also testified to by other sieges from the $1^{\text {st }}$ and $2^{\text {nd }}$ quarter of the $15^{\text {th }}$ century. In 1422 during a war between the Kingdom of Poland and the Teutonic Order, Polish troops which besieged the castle in Golub (PL) made use of bombardis maioribus when preparing an attack on the lower castle. On the other hand, machinis pro parte maiori debilitatum were applied for capturing the upper castle. ${ }^{23} \mathrm{~A}$ few years thereafter, in 1428, Grand Duke Vytautas of Lithuania was besieging the castle of Opoczka near Novgorod (RU) using bombardis, machinis et ligneis tormentis. ${ }^{24}$ Similar steps were undertaken

\footnotetext{
${ }^{20}$ Szymczak 1979, 52.

${ }^{21}$ Wagner et al. 1956, 80; Procházka 1982, 40.

${ }^{22}$ Contamine 1999, 112; DeVries and Smith 2012, 136.

23 Jana Długosza Roczniki..., ks. 11, 182; Joannis Dlugossii Annales..., liber XI, 173; Głosek 1990, 155.

${ }^{24}$ Jana Długosza Roczniki..., ks. 11, 257; Joannis Dlugossii Annales..., liber XI, 244; Głosek 1990, 155.
} 


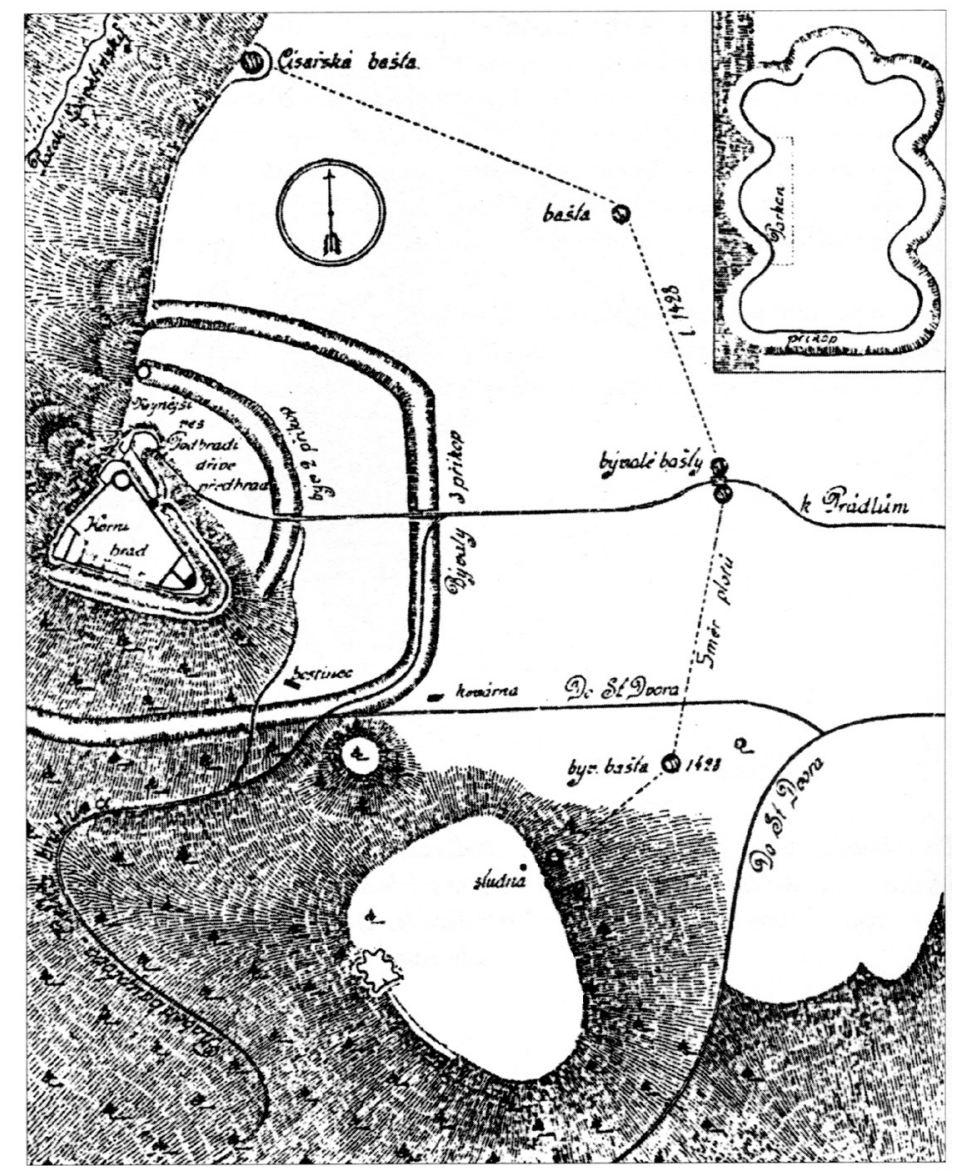

Fig. 9. Siege positions around Castle Lichnice. After Teplý 2007, Fig. 2.

by Hussite forces during the siege of a royal seat in Nový hrad near Kunratice (CZ) at the turn of 1420 and 1421. Apart from light artillery (terrace-guns), three trebuchets were also used. One of these was perhaps a traction trebuchet (Fig. 7), as suggested by source mentions which underline its small size and a high rate of fire. ${ }^{25}$ Regrettably, present-day examinations did not reveal the location of these posts, but the use of throwing engines was demonstrated by finds of numerous projectiles, including one entirely preserved $(40 \times 40 \mathrm{~cm})$. In all probability the engine posts were not especially prepared and they were protected by a double rampart with a cut. The distance between the rampart and the castle was about $140 \mathrm{~m}^{26}$

Sometimes it also came to duels between parties equipped with cannons and with throwing engines.

\footnotetext{
${ }^{25}$ Vavřinec z Březové Husitská..., 205-206; Laurentii de Brzezowa Historia..., 465-466: Et mox in vertice montis, qui Hrzeben in vulgari dictur, prope fossata castri tuguria et tentoria erigunt et disponunt et se ex omni parte circumfodiunt pro inimocorum defensa, de pixidibus et tribus machinis quottidie innumeros ad castrum lapides proiciunt, ita quod omnia tecta lapidibus machinarum concusserunt, et propinquius super fossata appropinquantes parvam erigunt machinam, de qua praczate propugnacula defendencium concusserunt.

${ }^{26}$ Drobná 1953, 197-200; Durdík 2009, 40, 389-390, Fig. 40; Kypta and Podliska 2014, 617, 621, Figs. 1-6.
}

Such a case, concerning the siege of Hradčany in 1420 , was described by a chronicler Vavřinec of Březová "At that time, the Prague troops and the Taborites inflicted a lot of damages to houses in Hradčany, shooting from throwing engines deployed in Pohořelci. The defenders, however, firing from cannons from Hrad and Hradčany, destroyed those throwing engines". ${ }^{27}$ Yet another "encounter" of this kind took place in August 1420 during the fights for Vyšehrad: "On the other side of the town they deployed two machines, i.e. throwing engines, behind the choir of the Holy Virgin church on the Botič. These, however, were destroyed by a skilful Vyšehrad master gunner, who fired from the round chapel of St. Margaret towards the Botič. On the other hand, with a large cannon which they deployed in the little church 'on Grass', having demolished its wall, they inflicted a lot of damage to the Vyšehrad people". ${ }^{28}$

\footnotetext{
${ }^{27}$ Vavřinec z Březové Husitská..., 71; Laurentii de Brzezowa Historia..., 377: De machinis vero in Pohorzelecz erectis per Pragenses et Thaboritas plurima dampna domibus in Hradczan inferebantur eo tempore, verumtamen easdem machinas de bombardis sagittantes illi de casto et Hradczan destruxerunt, see also Durdík 1954, 88.

${ }^{28}$ Vavřinec z Březové Husitská..., 151; Laurentii de Brzezowa Historia..., 432: ex altera parte scilicet civitatis duas machinas, praky retro chorum beate Virginis in Botiecz erigentes, quas tamen subtilis Wyssegradensis magister de capella rotunda Sancte
} 


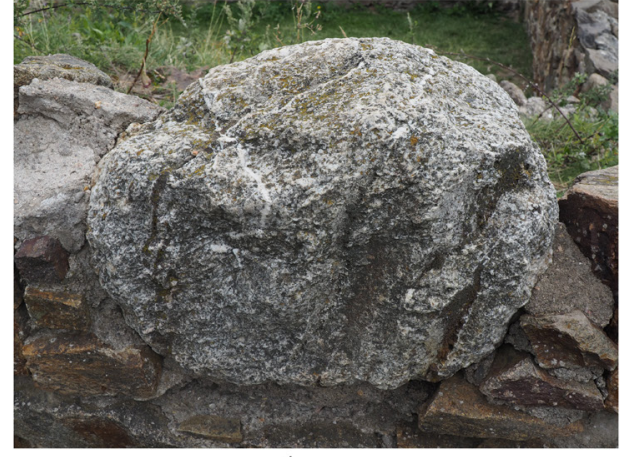

1

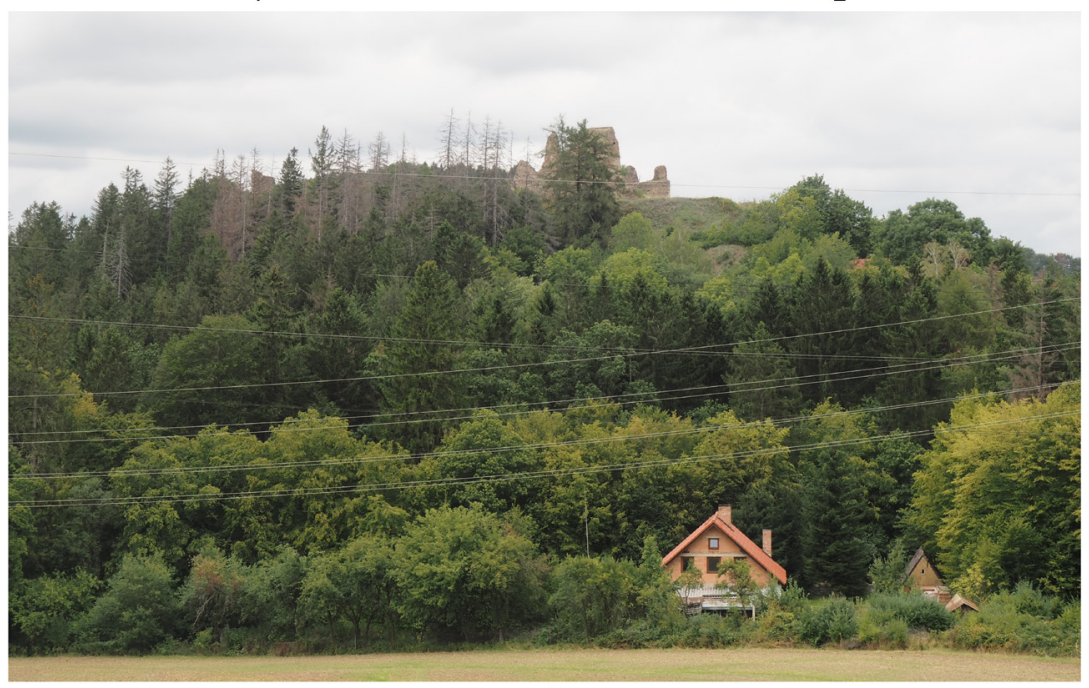

3

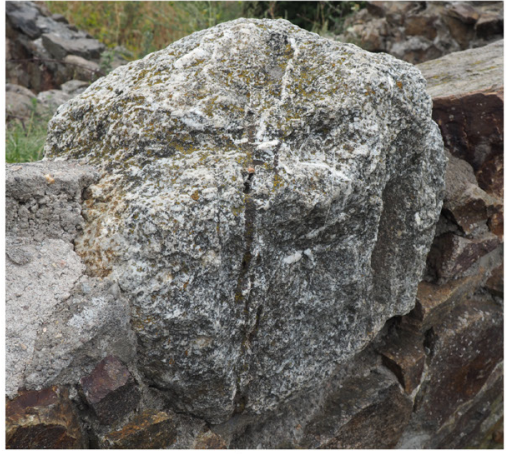

2

Fig. 10. Castle Lichnice. 1,2 - trebuchet projectile embedded into the masonry wall at the castle; 3 - view toward the castle from the direction of the siege post. Photo P. Strzyż.

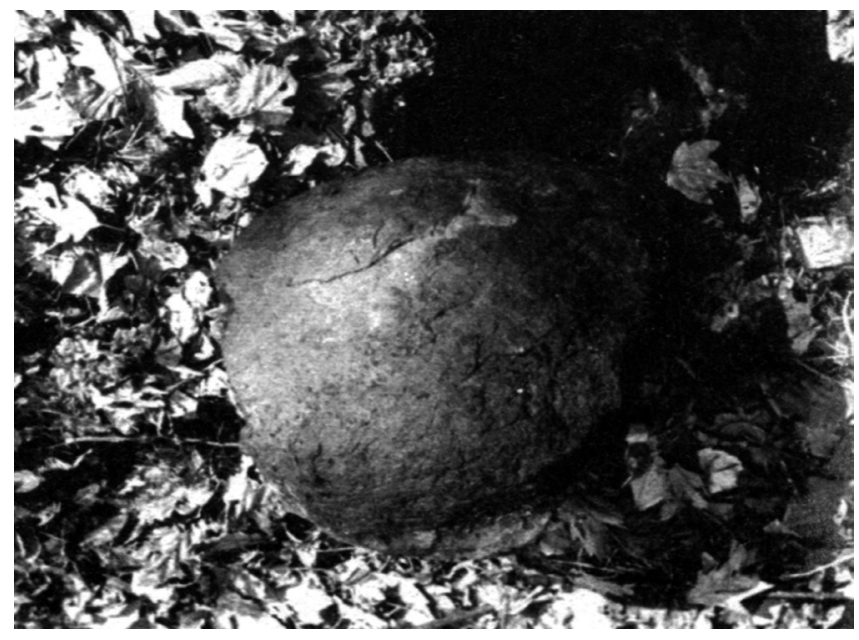

Fig. 11. Castle Lopata. Trebuchet projectile. After Novobilský 2008, Fig. 79.

The accuracy of trebuchets is demonstrated by an example from the siege of Mortagne in 1340, when in a duel of two engines of this kind one party was able to

Margarethe ad Botiecz sagittando corrupit; per pixidem vero magnam, quam in ecclesiola in Viridi muro rupto locaverant, mult dampna Wyssegradensibus intulerunt. hit the adversary with the third round. ${ }^{29}$ These pieces of information imply that the effectiveness of fire was first of all determined by the experience of engine crews.

Material traces for a simultaneous use of throwing engines and gunpowder artillery are also yielded by archaeological examinations of siege posts and battlefields from the $15^{\text {th }}$ century. Among more significant ones there were certainly hostilities at Castle Bechyně which lasted from 8 July to mid-October 1428 . Written sources from this period provide rather general pieces of information concerning these events.

In Staré letopisy české was written: "In that year before St. Gall's day [before 16 October 1428] priest Prokop the Bald, the commander of the Taborites, together with those who were subject to him, besieged the castle of Bechyně. They brought there all the cannons and deployed them in a crosswise manner. And because of great hardship the castle surrendered to them" ${ }^{30}$ Not

\footnotetext{
${ }^{29}$ Gravett 2018, 62.
}

${ }^{30}$ Ze starých..., 106: Téhož roku kněz Prokop Holý, vưdce Táborských, oblehl spolu z těmi, kteři se mu poddali, hrad Bechyni. Svezli sem všechna děla a rozestavěli je kř́žem, pro veliké utrpeni se jim hrad vzdal. An almost identical description is offered by 


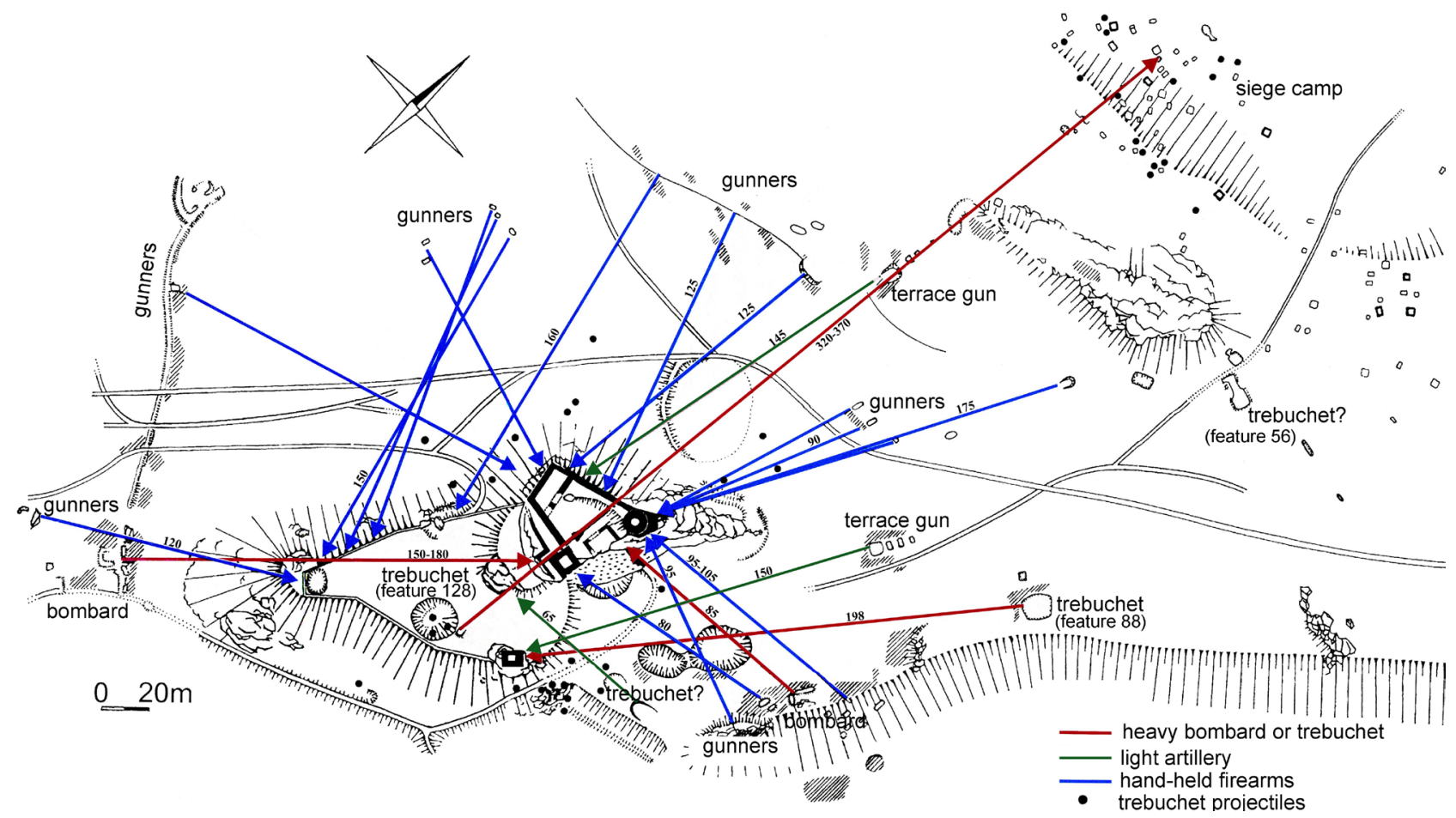

Fig. 12. Castle Lopata. Directions of fire of the besiegers and the defenders. After Novobilský 2008, Fig. 71.

much more precisely these actions were characterised by Bartošek of Drahonice: "On Thursday in the week before St. Margaret's day [8 July 1428] the Taborites laid siege to the castle and the town called Bechyně and they put up their camp around it from four sides. (...) They set up their wagons and remained there for about 15 weeks and attempted at taking the castle and the town by force, with the help of numerous large and smaller cannons and throwing engines". ${ }^{31}$

The castle was surrounded from every side so that individual segments of masonry walls could be destroyed. At the same time, we are informed that both gunpowder artillery and throwing engines were used for this purpose. Out of four posts that were mentioned in the vicinity of Castle Bechyně, only one survived until present. It is a low promontory situated in the bifurcation of the Rivers Lužnica and Smutná, to the south of the castle. Its distance from

Staré letopisy..., 92: "In that year before St. Gall's day Prokop the Bald with his supporters besieged the castle of Bechyně. And all the cannons were brought there and they were deployed in a crosswise manner. And the defenders had to surrender the castle because of great hardship".

${ }^{31}$ Bartošek of Drahonice, Kronika, 240; Bartossek de Drahonic, Chronicon, 598: Secta vero Thaborensium illa septimana feria $V$ ante festum Margarethe castrum et civitatem dictum Bechynie circumvallaverunt et in quator partibus circumiacuerunt, inter quos fuit capitaneus presbiter Procopius, et ibi circa XV septimanas iacuerunt castra metati et pixidibus magnis et minoribus multis et machinis ipsum castrum et civitatem lucrare per violenciam conantes. the castle's centre is about $250 \mathrm{~m}$. Its location was convenient, both due to protection offered by steep banks of the mentioned rivers and the elevation of about $20 \mathrm{~m}$ higher than the posts of the defenders. ${ }^{32}$ What was found there were four elongated features, which were perhaps trenches for battering cannons (Fig. 8:1), as well as larger terraces which were square in their plan and were perhaps meant to accommodate throwing engines ${ }^{33}$ (Fig. 8:2). On the $\mathrm{NE}$ an earthwork was additionally made (35 $\mathrm{m}$ long, $1 \mathrm{~m}$ high); (Fig. 8:3). It was perhaps a basis for a terrace which protected the eastern shooting line. ${ }^{34}$

Out of the prepared posts for throwing engines (Fig. 8:2), the dimensions of the westernmost one are $10 \times 11.5 \mathrm{~m}$. The second one is located closer to the centre and it occupies the space of $9 \times 10 \mathrm{~m}$. The easternmost post was probably meant to accommodate two throwing engines, which can be suggested by its size, i.e. $13 \times 20 \mathrm{~m}$. Their crews were protected from the north-east by a $1 \mathrm{~m}$ high earthwork. ${ }^{35}$ Apart from traces in the field, the use of throwing engines is evidenced by finds of three stone projectiles or their semi-products, with dimensions of 30-40 cm. ${ }^{36}$

Assuming that the aforementioned earthwork features were related to the use of siege artillery and

\footnotetext{
32 Kypta and Richterová 2004, 117, Fig. 1.

${ }^{33}$ Kypta and Richterová 2004, 120, Figs. 2 and 6.

${ }^{34}$ Kypta and Richterová 2004, 121, Figs. 2 and 6.

${ }^{35}$ Kypta and Richterová 2004, 121, Figs. 2 and 6.

${ }^{36}$ Kypta and Richterová 2004, 119.
} 


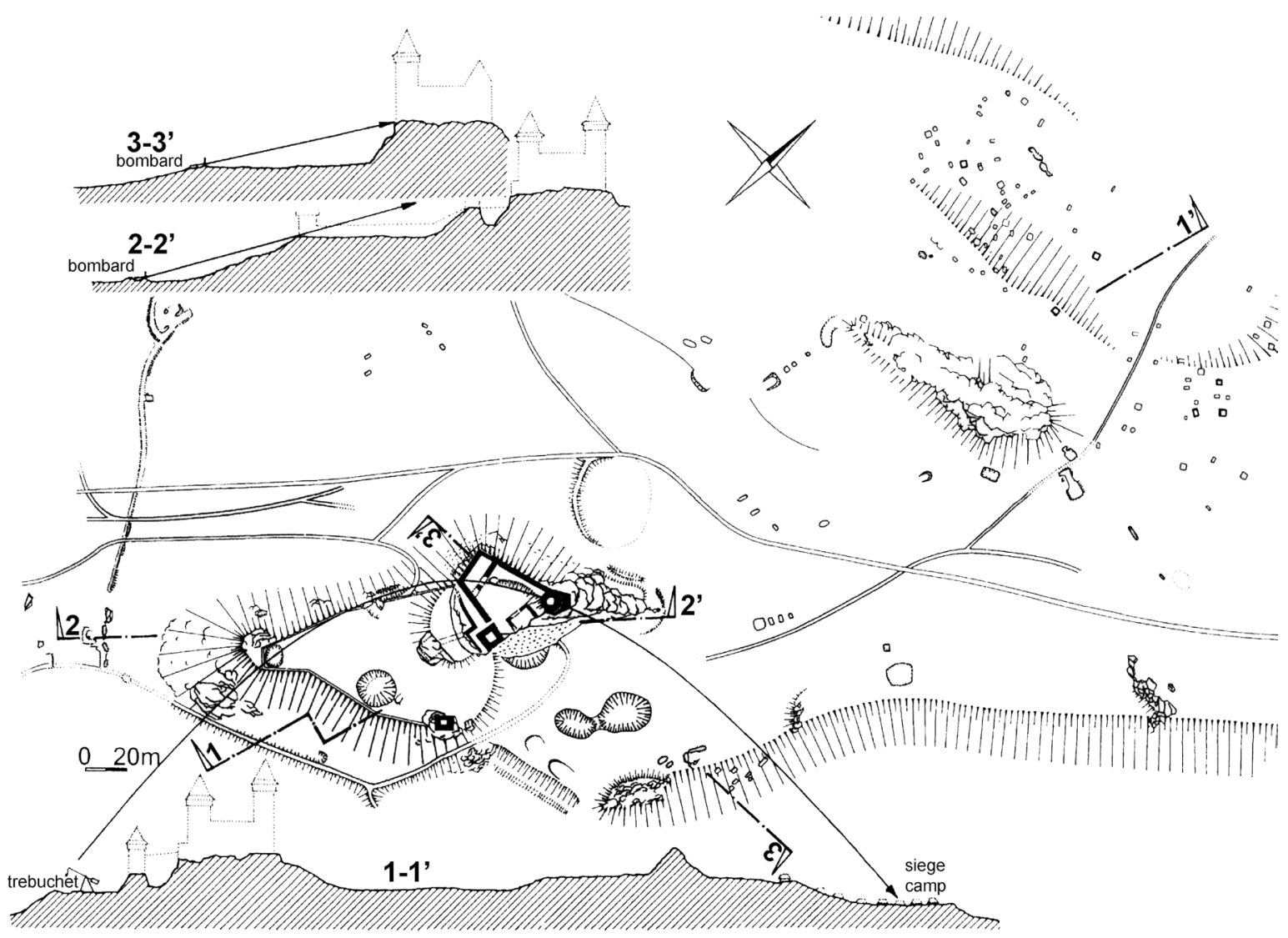

Fig. 13. Castle Lopata. Trajectory of cannon and trebuchet fire during the siege in 1432-1433. After Novobilský 2008, Fig. 80.

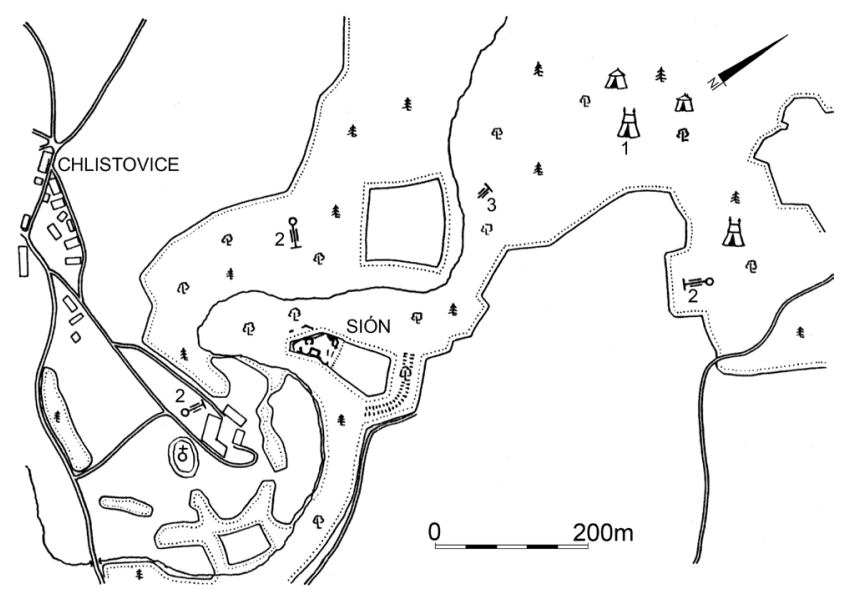

Fig. 14. Sión Castle. Reconstruction of the deployment of siege posts in 1437. 1 - siege camp; 2 - trebuchet, 3 - cannon. After Janská 1963, Fig. 78.

throwing engines, a considerable concentration of bombarding devices in one point must be underlined. This post may have accommodated as many as four cannons and three or rather four siege engines. Bearing in mind the presence of yet another three gun sites, it is of no surprise that the garrison decided to surrender the castle.

Sometimes archaeological examinations and field surveys enable the researcher to complete data available from chronicles. This is the case with the siege of Castle Lichnice, which lasted from July 1428 to November 1429. The chronicler Bartošek of Drahonice reported: "In this year, on Thursday and Friday after St. James' Day [29-30 July 1428] the Orphans (...) besieged the stronghold of Lichtenburg. They set up a camp there, they erected turrets or fortifications and fences around it, and solely stayed there, without using large cannons and throwing engines". ${ }^{37}$

Traces of siege were so legible in the field in the $19^{\text {th }}$ century that it was possible to precisely record them. The caste was protected with dense forests from the $\mathrm{W}$ and SW, and bombardment was only possible from the $\mathrm{E}$ and NE. Therefore, three cuts were made from these directions and these constituted the most advanced line of defence of the foreground. Seven turrets were constructed along these cuts. ${ }^{38}$ On the SE (Fig. 10:3) there was a premise which stood out with regard to its size. It was interpreted as a position of a throwing engine or

${ }^{37}$ Bartošek of Drahonice, Kronika, 240, 243; Bartossek de Drahonic, Chronicon, 599: Eodem anno feria $V$ et sexta secta Orphanorum, (...) castrum Lichmburg circumvallarunt et ibi castra metarunt et bastas sive fortalicia et sepes circumfecerunt et ibi solum iacuerunt pixidibus magnis et machinis non utentes.

${ }^{38}$ Sedláček 1900, 39; Menclová 1972, 220; Frolík 2002, 399, Figs. 1 and 2; Durdík 2009, 331. 


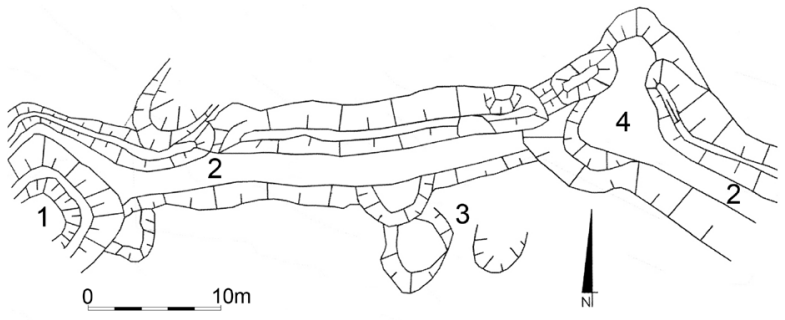

Fig. 15. Castle Sión. Southern firing position of the besieging troops: 1 - post of soldiers with hand-held firearms; 2 - trench with an earthwork; 3 - storage pits; 4 - artillery post. After Koscelník et al. 2013, Fig. 2.

as a commanding post, the latter interpretation being less probable. It was a polygon with seven corners and its size was $30 \times 60$ paces $^{39}$ (Fig. 9). It is unknown how intense siege actions were. Finds of globular projectiles for hand-held firearms are believed to be related to this siege and they testify to the use of hand-held guns. ${ }^{40}$ What is more, a stone projectile for a trebuchet was found. It was embedded into the masonry wall around the castle (Fig. 10:1-2). Other finds include a few cannonballs which are now part of the museum exhibition. This ammunition seems to contradict source reports, which inclines some researchers to propose that the trebuchet and the cannons were transported at the caste at some later time, after the siege had already begun. ${ }^{41}$

Traces of use of throwing engines are also notable in the case of Castle Lopata, which was besieged by Hussite forces from late October 1432 to early February 1433 . We are informed about this siege both by Staré letopisy české and by the chronicle of Bartošek of Drahonice. ${ }^{42}$ Fieldworks allowed for recording of traces of both artillery posts ${ }^{43}$ and of throwing engines.

\footnotetext{
${ }^{39}$ Teplý 2007, 467, Figs. 1-3.

${ }^{40}$ Frolík 2002, 402, Fig. 5:18-23; Strzyż 2014, 117.

${ }^{41}$ Teplý 2007, 467-468, Footnote 7.

${ }^{42}$ Ze starých..., 114: Téhož roku [1432] při postu před Všemi svatými oblehl pan Přibík z Klenového hrad Lopatu. (...) Protože nemohli hrad dobýti děly, vyhladověli ho. Když obránci poslední týden před masopustem už neměli co jist ani pit, zapálili hrad a utikali z něho pryč, ale zajali jich ke čtyřiceti, protože od hořicího hradu bylo veliké svétlo ("In this year [1432] during the fast before the All Saints' Day [31 October] Lord Přibík of Klenová besieged the stronghold of Lopata. As they were unable to capture the castle with cannons, they were starving the garrison. Before the Carnival, defenders had no food or drink, so they set the castle on fire and commenced to flee from it. However, about 40 of them were captured, as there was great light from the burning castle"). Bartossek de Drahonic, Chronicon, 609: Eodem anno feria II in vigilia sanctorum Simonis et Jude apostolorum Przibiko de Klenowy (...) circumvallaverunt castrum Lopata (...). Qui ipsum castrum defenderunt usque annun XXIIII usque festum sancte Dorothee et diucius pre fame et siti in dicto castro se defendere non valentes ipsum castrum soli incenderunt et, quo quis potuit, transiverunt.

${ }^{43}$ Novobilský 2008, 61-66, 69-70, Figs. 71, 73, 76-77, 81-82; Strzyż 2014, 194-199, Figs. 28-32.
}

This is especially significant, as the aforementioned sources do not report on the use of the latter. 36 stone projectiles for trebuchets were gathered altogether from the area around the castle. These were made from conglomerates, sandstone and quartz. They were not processed very carefully and their shape was oval rather than globular (Fig. 11). Their dimensions usually oscillated between $15 \times 20 \mathrm{~cm}$ and $30 \times 35 \mathrm{~cm}$, but finds with a diameter of about $50 \mathrm{~cm}$ were also discovered. ${ }^{44}$

In some points around the castle clusters of projectiles and ground preparation for possible deployment of engines were noted. The first point of this kind was situated to the east of the castle (feature 88). It was a rectangular area with dimensions of $10 \times 11 \mathrm{~m}$. It was oriented toward the southern rectangular tower of the forecastle. As many as nine cracked stone projectiles were found around this tower ${ }^{45}$ (Fig. 12). The second cluster (of seven) stones was discovered in the central part of the castle but the location of the engine which launched them is not certain. This may have been a post with dimensions of $13 \times 13 \mathrm{~m}$, situated on the south-western side of the castle at a distance of c. $60 \mathrm{~m}$ (Fig. 12). The trebuchet that was deployed there may have been aimed at a dwelling building near the western curtain of masonry walls. ${ }^{46}$ The third trebuchet belonging to the besiegers was situated in the western part of the siege camp to the north of the castle (feature 56). This is a rectangle with dimensions of $6 \times 6 \mathrm{~m}$ which implied that the trebuchet that was deployed there was smaller than the aforementioned ones. Its function may have consisted in having a fire duel with an engine possessed by the defenders ${ }^{47}$ (Fig. 12).

The latter deployed their engine in the forecastle, where there was also good access to rock material on which the castle was built. This trebuchet was aimed at the camp of the besieging troops which was located on the elevation of terrain to the north of the castle. 15 projectiles were found there altogether. The distance was quite considerable there and it was as much as $320-370 \mathrm{~m}$. What remains of the trebuchet's location is not the post itself, but a large cavity in the rock (its diameter is about $15 \mathrm{~m}$ - feature 128). It came into existence in result of extraction of raw material for making projectiles (Fig. 12). Yet another three stone projectiles were found on its bottom. The weight of these stones is $60-80 \mathrm{~kg}$ on average..$^{48}$ It was calculated that the capacity of the pit in the forecastle was about $200 \mathrm{~m}^{3}$, which theoretically allowed

\footnotetext{
${ }^{44}$ Novobilský 2008, 66-67, 86, 131, Fig. 79.

${ }^{45}$ Novobilský 2008, 49, 66, Figs. 70-71, 84.

${ }^{46}$ Novobilský 2008, 66, Fig. 71.

${ }^{47}$ Novobilský 2008, 46, 67, Figs. 57, 70-71.

${ }^{48}$ Novobilský 2008, 67, Figs. 11, 70-71, 80, 84 .
} 

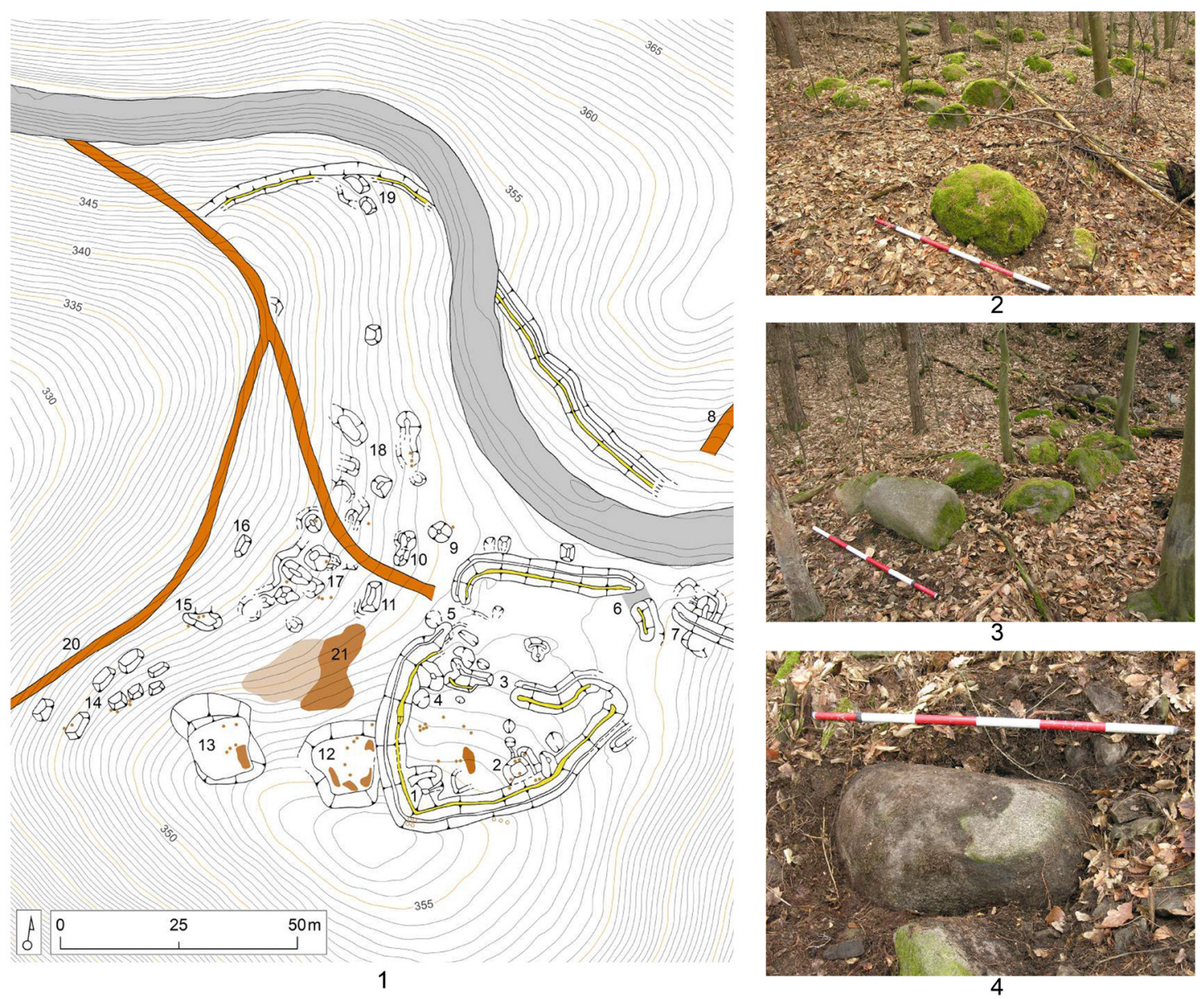

Fig. 16. Castle Kostelec. 1 - northern siege post (Subcomplex C), 2-4 - stone projectiles for trebuchets. After Kypta et al. 2016, Figs. 4, 9-11.

to carve about 7,000 projectiles. The use of the trebuchet by the defenders was the only possible response to the enemy fire, as a possible use of flat-trajectory bombards was rendered difficult by dense castle buildings ${ }^{49}$ (Fig. 13).

Concerning a simultaneous use of engines and cannons, significant data was yielded by finds related to the siege of Castle Sión in 1437, which belonged to Jan Roháč of Dubé. In the course of archaeological examinations in the 1960s a considerable assemblage of ammunition was gathered. It was first of all composed of trebuchet projectiles -38 pieces altogether. These were roughly carved only and were found in more numerous clusters mainly in the western part of buildings, including the area near the rectangular tower and the so-called "palace". A geological analysis demonstrated that rock material for their manufacture was acquired in the immediate vicinity of the castle. Finds of ammunition for throwing engines were accompanied by stone cannonballs. Their diameters varied from $9.5 \mathrm{~cm}$ via $11.5-18 \mathrm{~cm}$ to as much

${ }^{49}$ Novobilský 2008, 67, Fig. 80 as $29-30 \mathrm{~cm}$ (perhaps for terrace-guns, field cannons and bombards). The total number of engine and cannon projectiles was about 100 . What was also found was ammunition for hand-held firearms. On the basis of the examinations it was possible to assume that a few posts with throwing engines and artillery were set up around the castle ${ }^{50}$ (Fig. 14).

A confirmation of these findings was brought by more recent field surveys from the years 2011-2012. In result of these, both the military camp and the remains of the firing position to the S-W of the castle were localised. The position was situated on a horseshoe-shaped ridge with dimensions of $5 \times 10 \mathrm{~m}$, which was located near the end of the River Vrchlice's valley. A number of constructions were discovered there. They were interpreted as posts for combatants with hand-held firearms, artillery and military supplies ${ }^{51}$ (Fig. 15). Search in the foreground of the castle from the N-W to the S-W yielded finds of another some dozen projectiles for hand-held

${ }^{50}$ Janská 1963, 234, 236-238, 242, 244, Figs. 75, 78; Janská 1965, 39-42, Figs. IX:7-8, XXIII, XLII-XLV.

${ }^{51}$ Koscelník et al. 2013, 578-579, 582, Fig. 2; Strzyż 2014, 199-200, Fig. 33. 


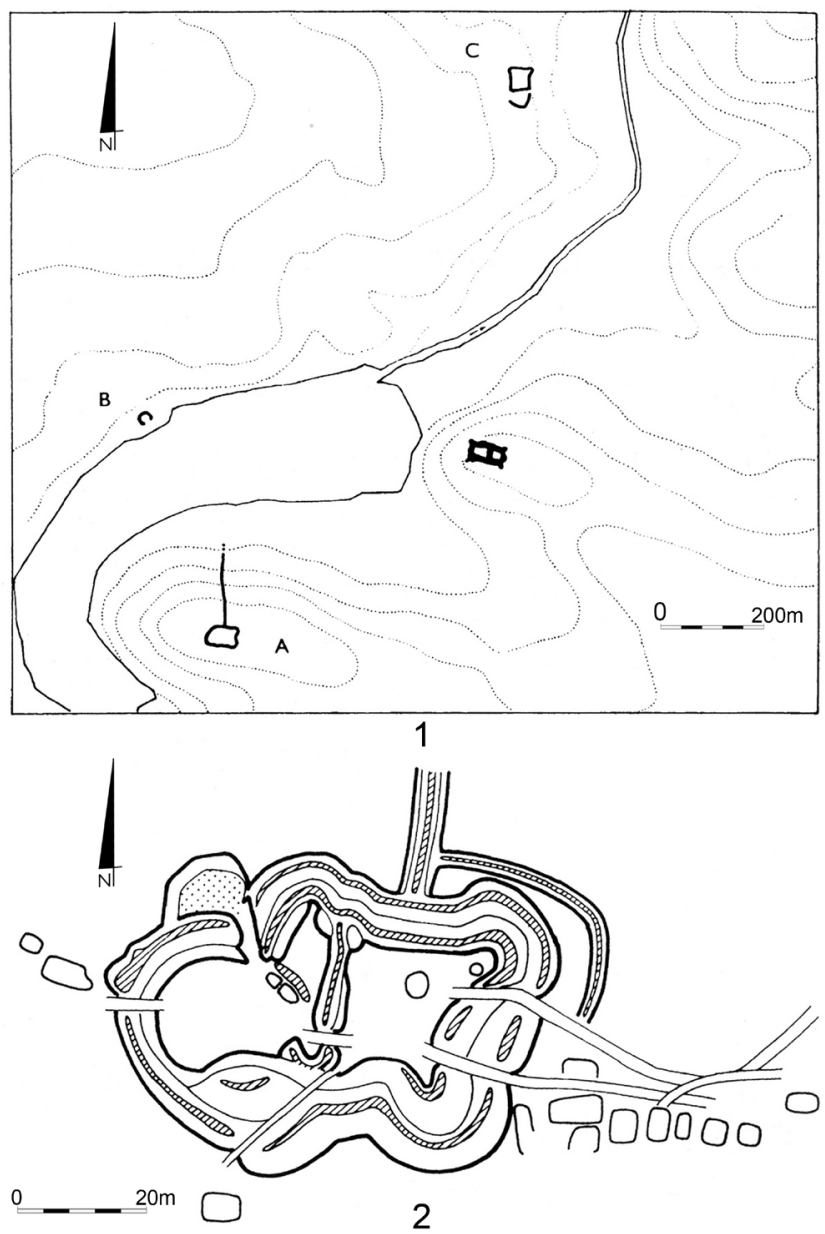

Fig. 17. Castle Konopiště. 1 - deployment of siege posts around the castle, 2 - complex A. After Meduna 1994, Figs. 1 and 2.

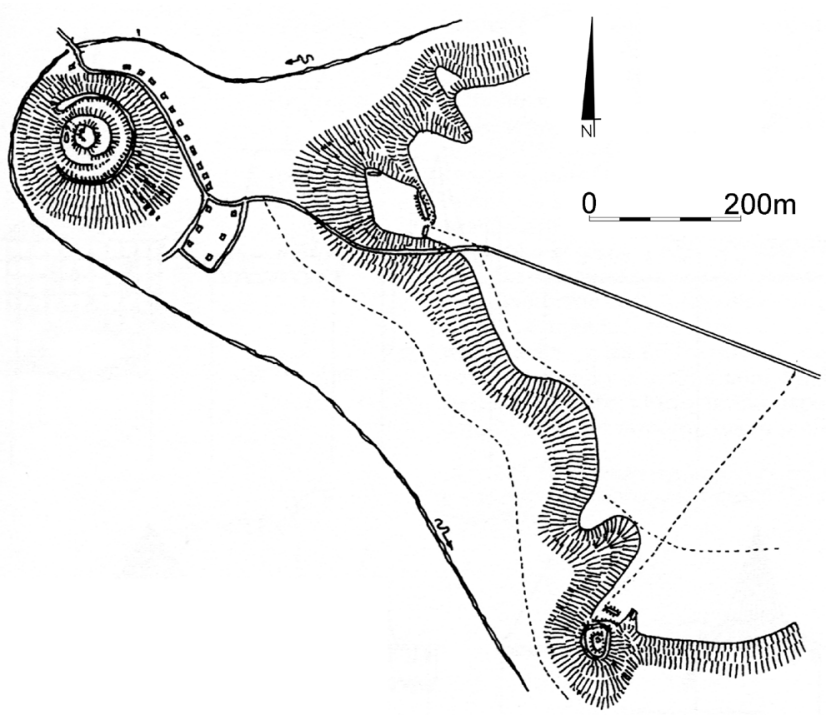

Fig. 18. Castle Velký Vřeštov and the siege post. After Durdík 2009, Fig. 1267.

firearms. On the other hand, no new discoveries of ammunition for throwing engines were made. ${ }^{52}$

\footnotetext{
${ }^{52}$ Koscelník et al. 2013, 589-590, 593, Figs. 3-5, 10; Strzyż 2014, 200-201, Fig. 34, Tab. CVIII:5-30.
}

Further pieces of information on parallel use of throwing engines and artillery are known from as late as the $2^{\text {nd }}$ half of the $15^{\text {th }}$ century. For 1451 we have accounts which testify to their use during the siege of Castle Perštejn (CZ). On Saturday 22 May the following sums were spent: "For renovation of a siege engine (balista) in the court 4 Groschen and for Král for purifying of a protective cover (testudo) 4 Groschen. On 24 July the following money was paid: For Petr the master-gunner 1 three score Groschen and on 31 July: For Michalec for 2 wheels for a cannon and for other required items 16 Groschen, for wax for a cannon 4 Groschen 4 Crowns and for powder for the same cannon 5 Groschen 2 Crowns". ${ }^{33}$

Other examples of simultaneous use of throwing engines and artillery are related to military events from 1467. In this time King Jiři of Poděbrady "with his faithful lords gathered troops and during the week after St. George's Day besieged the following castels: Roudnici, Hradištko near Roudnice, Šternberk, Konopiště, Leštno, Kostelec upon Sázava, and Hradec troops besieged the stronghold of Vrrešt'ov belonging to Lord Zajíc. Roudnice was besieged for a quarter of the year and it was eventually captured. Then, Kostelec was taken and destroyed and after that Leštno was captured and burnt down. Then, Šternberk upon Sázava was captured and destroyed. In this year the king also captured Chwatěruby". ${ }^{54}$

Castle Kostelec that was mentioned by the chronicler was besieged as many as three times: in 1449 , 1450 , and in $1467 .{ }^{55}$ After these hostilities, a few siege posts survived until present around the castle. These posts are marked now as Subcomplexes A-F. ${ }^{56}$ The use of both artillery and throwing engines is first of all evidenced by a letter of Friedrich Voivode of Saxony from 15 May 1450, in which he informs that "there are heavy works on the castle with guns and throwing engines". ${ }^{57}$ As regards the identified features, the most significant for our research is the post marked as Subcomplex C (Fig. 16:1). It is situated at a distance of about $310 \mathrm{~m}$ to the $\mathrm{N}$ of the castle and is

\footnotetext{
${ }^{53}$ Koscelník and Jukl 2012, 220.

${ }^{54}$ Ze starých..., 194: král se svými věrnymi pány shromáždil vojsko a hned v týdnu po sv. Jiři oblehl tyto hrady: Roudnici, Hradištko u Roudnice, Šternberk, Konopiště, Leštno, Kostelec na Sázavě a Hradečtí oblehli panu Zajicovi Vřeštov. Roudnici obléhali přes čtvrt roku, až ji nakonec dobyli. Pak dobyli Kostelec a rozbořili jej, potom dobyli a vypálili Leštno, pak dobyli a pobořili Šternberk na Sázavě. A téhož roku král dobyl také Chwatěruby.

${ }_{55}$ Meduna 1984, 119; Durdík 2009, 625; Kypta et al. 2016, 96, 99 .

${ }^{56}$ Meduna 1984; Kypta et al. 2016.

${ }^{57}$ Listár..., 206, no. 282: slos harte arbeiten mit buchsen und bleyden.
} 


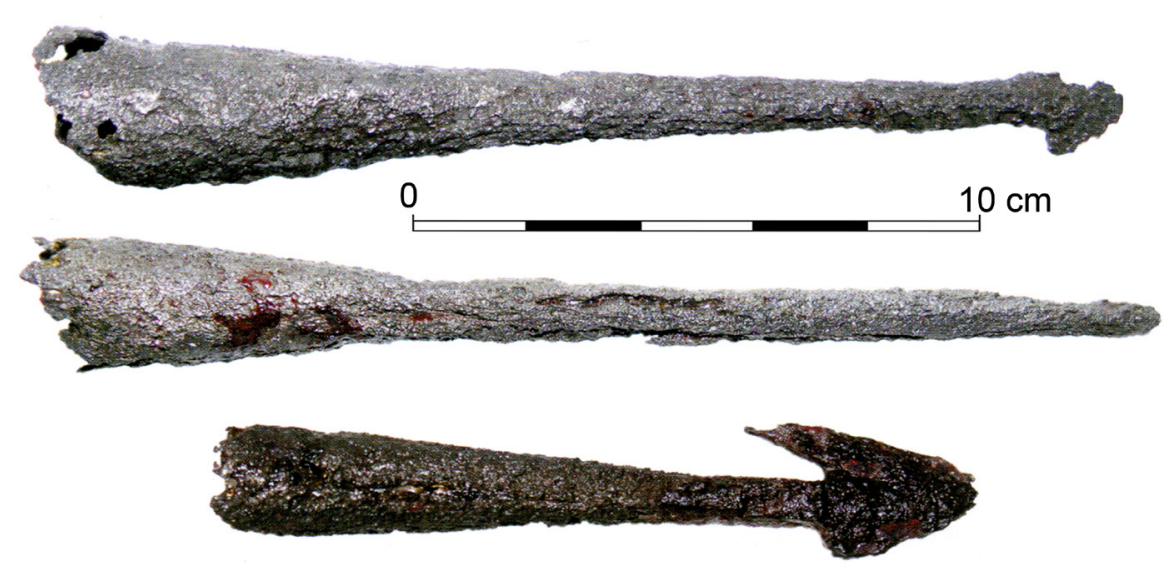

Fig. 19. Tovačov. Ballista bolt heads. After Žákovský and Schenk 2017, 110.

located c. 40-50 m higher than the castle itself. At this site, the whole camp of the besieging troops and two throwing engines were deployed. Posts for these devices are rectangular - the site of the eastern one is $14 \times 10 \mathrm{~m}$, while the western one is located about $15 \mathrm{~m}$ from the eastern one and its size is $14 \times 12 \mathrm{~m}$. Near these posts a considerable number of projectiles made from local rocks were found. These projectiles were often rather crudely processed and their length was from 60-70 to even $90 \mathrm{~cm}^{58}$ (Fig. 16:2-4). Furthermore, Posts D and E were also identified as possible artillery posts. These were located at a distance of about $190 \mathrm{~m}$ from the castle..$^{59} \mathrm{In}$ all probability both posts (Subcomplexes D and E) come from as early as 1449 or 1450 . On the other hand, the camp and the trebuchet posts (Subcomplex C) are rather related to the campaign of 1467 . It is also probable that they may have come into existence as early as 1450 (which is implied by the aforementioned letter) and in 1467 they were used again. ${ }^{60}$

The siege of Castle Konopiště also left permanent traces in the field (Fig. 17). It must be stated, however, that this premise was defended for much longer than Kostelec and it surrendered as late as December 1468. Field surveys allowed for recording of six posts, out of which three (Complexes A-C) may be quite certainly related to the events from the years 1467-1468. Complex A is a polygonal area surrounded with ramparts, and small turrets were constructed in its corners. The feature was identified as a prak post, while light cannons may have been deployed in its corner turrets. ${ }^{61}$ On the other hand, in more recent literature

${ }^{58}$ Meduna 1984, 124-125, 127, Figs. 1-2, 4; Kypta et al. 2016, 102-106, Figs. 4, 8-11.

${ }^{59}$ Meduna 1984, 122, Figs. 1-2; Kypta et al. 2016, 106-107, Fig. 5:1-2.

\footnotetext{
${ }^{60}$ Meduna 1984, 127; Kypta et al. 2016, 113.

${ }^{61}$ Meduna 1994, 243-244, 248, Figs. 1-2.
}

this feature was discussed as a commanding post. ${ }^{62}$ Concerning Complex $\mathrm{C}$, it consisted of two parts and the northern one had corners which were also provided with turrets. ${ }^{63}$

Eventually, as regards Castle Velký Vřešt'ov, it was also captured in 1467. It was besieged from a post that was situated about $300 \mathrm{~m}$ to the SE of the castle (Fig. 18). The siege post itself was surrounded with a rampart and a moat, and in its NW part there was a $6 \times 16 \mathrm{~m}$ space. It may have been meant to deploy a trebuchet or trebuchets. It can be noted that their alignment is analogous to that of the posts at Castle Kostelec. $^{64}$

The discusses sieges from the period of rule of Jiři of Poděbrady demonstrate the use of throwing engines (in all probability trebuchets) together with gunpowder artillery as late as the $3^{\text {rd }}$ quarter of the $15^{\text {th }}$ century. Concerning the hostilities at Castle Kostelec, the northern post was provided with trebuchets and it even played a key role in the siege. If one assumes that the aforementioned interpretations of the recorded features are valid, it must be noted that in the case of Castles Kostelec and Velký Vřeštov this distance was up to $300 \mathrm{~m}$, which is convergent with the maximum range of fire of the engine from Castle Lopata. ${ }^{65}$

Without getting into detail, it is also worth saying that for the 1460 s the presence of features that can be interpreted as throwing engine and artillery posts was also recorded in the case of sieges of such castles from the territory of the Kingdom of Bohemia as, e.g. Cornštejn, ${ }^{66}$

\footnotetext{
${ }^{62}$ Kypta and Richterová 2003, 37-38. It is pointed out that numerous engineering works were also carried out around Castle Konopiště during the Second World War, see Kypta et al. 2016, 107.

${ }^{63}$ Meduna 1994, 244, 248, Figs. 1 and 4.

${ }^{64}$ Kypta and Richterová 2003, 37, 39-40; Durdík 2009, 588589, Fig. 1267.

${ }^{65}$ Cf. Koscelník and Juk1 2016, Fig. 3.

${ }^{66}$ Měřínský and Plaček 1991; Sýkora 2015, 42-45, Fig. 40.
} 


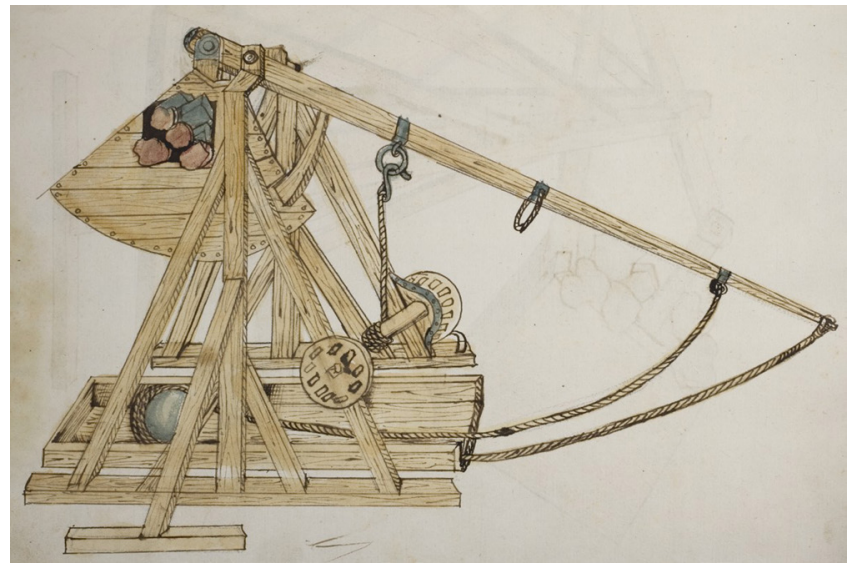

Fig. 20. Design of a blida (movable counterweight). Kriegsbuch, Philipp Mönch, c. 1496, Heidelberg, Cod. Pal. germ. 126, fol. 30.

Stará Dubá, ${ }^{67}$ Český Šternberk ${ }^{68}$ or Zlenice. In the latter case, apart from a cannonball, a stone projectile with a diameter of about $16 \mathrm{~cm}$ was also found. It may have been used for a ballista ${ }^{69}$ or rather for a trebuchet.

Finds from the vicinity of Tovačov can also be related to the period of rule of Jiři of Poděbrady. On 12 July 1470 near this locality it came to an atypical battle or rather an attempted ambush by troops of Matthias Corvinus. It was aimed against a military train under the command of an experienced leader Václav Vlček of Čenov ${ }^{70}$ which became overextended during the march. The putative spot of hostilities yielded a high number of weaponry finds, including 41 crossbow bolt heads and a fragment of the barrel of a hand-held gun with a calibre of $1.5 \mathrm{~cm} .{ }^{71}$ What is the most interesting, however, is a discovery of three bolt heads with long sockets and barbed blades (Fig. 19). Their total length is between 129 and $193 \mathrm{~mm}$, their socket diameter is $19-25 \mathrm{~mm}$ and their weight is $63-86 \mathrm{~g}$. It is possible that these are bolts for throwing engines such as ballistae or great crossbows, and their long sockets may have additionally facilitated the use of flammable materials. ${ }^{72}$

From 1471 there comes a letter written by Hans Nozispier, a carpenter from Nový Hrad, to Jan of Rožmberk concerning a payment for a manufactured trebuchet: "High-born Lord (...). As Your Lordship desires to know what we have done concerning the trebuchet manufacture, let Your Lordship condescend to make a contract with us for this work (...) And what was given to us for this work is: first of all, I, Hanzl

\footnotetext{
${ }^{67}$ Durdík 1981, 156-158, Fig. 5; Kypta et al. 2016, 107-108.

${ }^{68}$ Durdík 1982; Kypta et al. 2016, 107. The use of throwing engines may be suggested by the name of one of these sites which is called Na praku.

${ }^{69}$ Durdík 2011, 565-568, Fig. 4:1-7.

${ }^{70}$ Frankenberger 1960, 116-117, Fig. 27.

${ }^{71}$ Žákovský and Schenk 2017, 42, 45, cat. nos. 193-233, 251.

72 Žákovský and Schenk 2017, 44, cat. nos. 190-192.
}

Nozispieř, received 1 three-score from the burgrave of Nový Hrad, and I divided this among the workers. Then, Krajcar received 1 Hungarian Florin in Krumlov, as he was setting the trebuchet up. Then, Pavel the carpenter received 1 three-score in Krumlov and 0.5 three-score from the burgrave of Nový Hrad. And we have no more demands concerning this trebuchet" ${ }^{73}$

It is possible that the latest material evidence of use of throwing engines in sieges comes from Castle Věžka (CZ). This small premise was constructed perhaps before 1351 and it was in use only to 1478 , when it was captured and destroyed by Plzeň forces and troops of Matthias Corvinus King of Hungary. In the meantime, however, it was also successfully besieged by troops of King Václav IV. Amateur archaeological excavations carried out in 1962-1972 yielded finds of various weaponry. At present, there is no detailed information on these, but surviving photographic records allow to conclude that apart from firearms ammunition trebuchet projectiles were also found. ${ }^{74}$ Due to deficiencies in research methods, it is, however, not absolutely certain to what military action these projectiles can be related.

At the turn of the $3^{\text {rd }}$ and $4^{\text {th }}$ quarter of the $15^{\text {th }}$ century there are no more source data and material traces of military use of throwing engines in hostilities in the Kingdoms of Poland and Bohemia. The status quo in Western Europe was similar, as isolated cases of use of such devices are dated to the $1460 \mathrm{~s}-80 \mathrm{~s} .{ }^{75}$ On the other hand, throwing engines remained a significant kind of siege devices that were mentioned in military codices from the late $15^{\text {th }}$ and even the $16^{\text {th }}$ c. (Fig. 20). This is also evidenced by so-called Ksiegi Hetmańskie (Hetman Books) of Stanisław Sarnicki from 1575. In this book, the author partially included his experiences from travels to Italy (Padua, Trident, Venice), which he completed with pieces of information acquired from his reading of Italian tacticians, just to mention Roberto Valturius. ${ }^{76}$ In the introduction, he remarked that: "These structures, towers, testudines [a sort of wheeled

${ }^{73}$ Archiv..., 200-201, no. 1951: Urozený pane (...). Jakož VMt žádáte véděti, co sme vybrali od diela praku, a že by VMt ráčili smlúvu s námi učiniti za to dielo. (...) A toto jest nám vydáno na tom dielu: Najprve já Hanzl Nozispieř přijal sem 1 kopu od purkrabie Nového Hradu a to sem rozdělil mezi dělnikky. Item, Krajcar přijal zlatý uherský v Krumlově, jak prak stavěl. Item, Pavel tesar̆ přijal na Krumlově 1 kopu a od purkrabie Novohradského přijal $j$ kopy. A viece na tom dielu nie máme do toho praku.

${ }^{74}$ Hložek and Menšík 2017, 317-318, 321, Figs. 17-18, 55, 59.

${ }^{75}$ Contamine 1999, 205; DeVries and Smith 2012, 136-137; Gravett 2018, 62 - e.g.: Burgos (Spain) 1475-1476, Rodos 1480, probably Cembalo (the Crimea), 1475, see Dyachkov 2011, 175176, Figs. 3 and 4.

${ }^{76}$ The work of Valturius was a significant inspiration for Stanisław Sarnicki, who simply copied part of illustrations from the original, see Sikorski 1991, 111. 


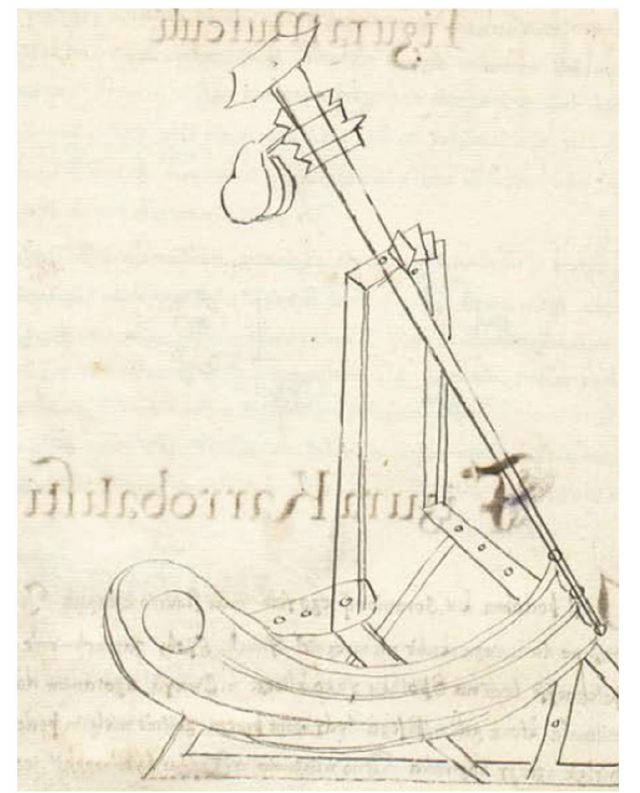

1

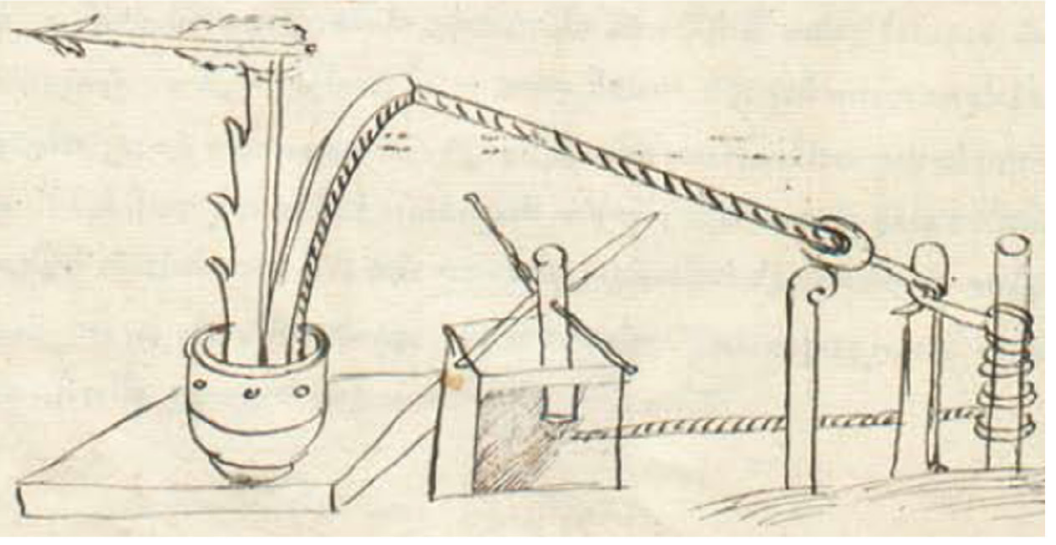

2

Fig. 21. Księgi Hetmańskie..., c. 1575. 1 - carrobalista, 2 - catapult. After Księgi Hetmańskie..., Figs. 34-35.

movable covers, a so-called turtle] from the old ages were of great service. However, when cannons went into use, these can be found more sporadically. Anyway, we will mention them here, too, so that we do not forget the ingenuity of men from the past". ${ }^{77}$

The first engine Sarnicki discussed was a carrobalista, that is, an engine that "is similar to a well sweep used for taking water from the well. In the place of the bucket, a projectile is attached with strong ropes. In order to make the impact stronger, a considerable counterweight is added, similar to the log of the well sweep. As the counterweight is released, the sling shoots at great velocity and it destroys large objects. However, it requires strong binding in the bottom part, as it can be seen in the case of windmills, which are rolled to where one wishes". ${ }^{78}$

The other machine which was discussed in a more detailed manner was a catapult, or "some sort of a very strong spring at a pole, which can shoot a trihedral bolt, called a triface, with great force. And there

\footnotetext{
${ }^{77}$ Księgi Hetmańskie..., 138: Te budowania, wieże, testudines ze starych wieków, kunszty byli pożyteczniejsze. Ale jako działa nastały mniej onych dzierża. Wszakoż abyśmy też ingenium liudzi starych nie zabaczyli tedy ich tu spomnimy.

${ }^{78}$ Księgi Hetmańskie..., 190, Fig. 34: jest podobna ku żurawiowi co jem wodę studniej ciagna, jeno kędy cebrzyk wysiwa, tu wiaże kulie na mocnych linach, a iżby zamachnienie uderzenia było potężniejsze, tedy na spodku jako kliocze wyszywaja u żurawiów dadza wagę dobrze niemała, która gdy wypuszcza tedy ona proca zbytnie wielgim pędem dmuchnie $i$ wielgie rzeczy rozwalia, jeno wiąania $w$ spodku trzeba zbytnie mocnego, jak widamy, a bywa u mlynów wietrznych, które mlyny przetaczają gdzie chce.
}

are notches in this pole which are used for aiming the triface at the target" ${ }^{79}$ From this description it follows that the author probably had in mind a bricole-like machine, i.e. a vertical pole with an elastic beam attached to it at the bottom. Its bending and then releasing caused a massive bolt to shoot on a flat track. ${ }^{80}$ Interesting is also the mention of the use of a sightseeing device for it.

\section{Diversification of siege ammunition}

A considerable difficulty in research on the popularity of use of throwing engines in the Late Middle Ages is the problem of identification of their ammunition, both concerning stone projectiles ${ }^{81}$ as well as metal missiles (bolt heads, balls). In this context, interesting data was yielded by archaeological research at Castle Tepenec (CZ). This castle was built around 1340. In result of internal conflicts in Moravia it fell into ruin as early as c. 1400. Apart from ammunition referred to as field cannon projectiles (cannonballs with diameters of 15 and $22 \mathrm{~cm}$ ), also such finds were gathered which can be considered traces of use of throwing engines. These projectiles were termed "loaf-shaped forms" they were strongly flattened in lateral projection and were round in projection from above. Eight finds were

\footnotetext{
${ }^{79}$ Księgi Hetmańskie..., 191, Fig. 35: prężyna niejaka przy niejakim słupcu barzo tęga, także bett troisty, który zowa trifacem, może wielka moca pognać. A w tem stupku sq karby, po których przerzeczony trifacem namierzaja do celiu.

${ }^{80}$ Jurga 1995, 34, Tab. XII.

${ }^{81}$ E.g. Mazáčková 2013, 272, Fig. 12.
} 
discovered altogether and the largest one had a diameter of $19.5 \mathrm{~cm}$ and stood out with regard to its quite carefully processed surface. The remaining ones were somewhat smaller - between 10 and $15.5 \mathrm{~cm}$ - and were only roughly carved. These finds were considered ammunition for so-called traction trebuchets and it was found out that they may have come from the castle's defenders. ${ }^{82}$

Research in the ruins of the Carthusian monastery in Dolany (CZ) also yielded diversified finds of ammunition. The monastery was built in the years 13881409. During the revolution, Hussite troops raided and captured the monastery on 2 February 1425 . Then, they fortified it and turned it into a post for attacking Catholic Olomouc. Local troops often launched expeditions against the Hussites and, as it is evidenced by source mentions, engines and siege artillery were also used for this purpose. In the next year, the town decided to redeem the monastery from Hussite hands. In order to prevent it from becoming a point of danger in future, it was decided to pull the monastery down. ${ }^{83}$ Archaeological research at the monastery yielded numerous projectiles. These are bombard cannonballs. One of these (40.5 cm in diameter, $91 \mathrm{~kg}$ weight) was split in two, which may suggest that it was found in a spot where it originally hit. It may have been fired from a post on the southern slope of Hék Hill. The second cannonball was somewhat larger (diameter $44 \mathrm{~cm}$ ), was provided with two crossed hammers incised on its surface and it was in all probability fired from a post on the eastern slope of the mentioned hill. ${ }^{84}$ Apart from cannonballs, a diversified assemblage of ammunition for throwing engines was also gathered. One of these was a globular projectile which survived in its $1 / 8^{\text {th }}$ part only. Its dimensions were $42 \times 50 \times 24 \mathrm{~cm}$ and it was deposited near the southern wall of the monastery. In another place a fragment of a window frame $(60 \times 50 \times 30 \mathrm{~cm})$ was discovered. It was made from different raw material than that of the monastery's walls. According to researchers, this implies that this block was also used as ammunition. An angular stone block with dimensions of $55 \times 36 \times 32 \mathrm{~cm}$ may have been a similar case. It was discovered near the cemetery. Spheroid or pebble-shaped (only roughly processed) stone blocks which were deposited in various parts of the monastery's buildings were also considered ammunition. ${ }^{85}$

\footnotetext{
${ }^{82}$ Novotný 1970, 63; Burian 1985, 21, Fig. on p. 23; Tymonová 2002, 221-225, 226, Fig. 9.

${ }^{83}$ Burian 1966a, 8-9, 10, 12-13; Měřínský 1980, 38.

${ }^{84}$ Burian 1966a, 12, Fig. on p. 11; Burian 1966b, 14; Měřínský 1980, 39, Fig. 2; Burian 1985, 21-22, Fig. on p. 24.

${ }^{85}$ Burian 1966a, 12; Burian 1966b, 14; Měřínský 1980, 39; Burian 1985, 21-23, 24-25.
}

The research at the discussed sites of Tepenec and Dolany, as well as at the aforementioned Castles Karlštejn, Lichnice and Kostelec (Fig. 4, 10:1-2, 16:2-4), confirm that throwing engine ammunition did not need to be as carefully processed as projectiles for firearms. Rock material and even fragments of masonry architecture such as, e.g. window details, could also be used as throwing engine ammunition. What was more important than the degree of processing was the projectile weight, as a similar weight secured approximate range, and in result of it, the accuracy of fire. However, it is fairly difficult to properly interpret such ammunition if is not accompanied by good archaeological context.

\section{Conlusions}

The source information allows us to notice that various types of throwing engines were still towering over the early artillery in the $15^{\text {th }}$ century with their speed of fire. In the case of siege Castle Karlštejn, we know that most of the bombards fired only 6-7 shots per day, and only Rychlica cannon, which may have been a big veuglaire, ${ }^{86}$ fired about 30 times per day. ${ }^{87}$ Such a low rate of fire was caused by the necessity of thorough cleaning of the cannon after each shot, so as to remove all the unburned gunpowder residue from the chamber and to cool down the barrel which was intensely heated during the shots. These problems did not occur when firing from the throwing engines, whose speed of shooting was determined by the only rigour and experience of the operator.

Therefore, in the case of Castle Karlštejn P. Koscelník calculated - assuming a total number of 10,866 projectiles of various kind that were fired and 171 days of the siege time - that one engine could launch 13 projectiles per day on average and all five engines were firing 63 missiles per day at the defenders. ${ }^{88}$ Calculations for the engine of the defenders of Castle Lopata may suggest that the raw material obtained from the rock deposit in the forecastle (about $200 \mathrm{~m}^{3}$ ) could be used for the manufacture of about 7,000 projectiles. Depending on the source, the siege of the castle lasted from 27 or 31 October 1432 to 6 February 1433, that is, about 100 days. Therefore, the trebuchet of the defenders could launch 60-70 projectiles per day. This, however, was considered not very likely. ${ }^{89}$ On the other hand, such a rate of fire was perhaps not the peak of efficiency of such engines. In 1147, during the siege of Lisbon two engines (but rather of the traction trebuchet

\footnotetext{
${ }^{86}$ Strzyż 2014, 100-101.

${ }^{87}$ See footnotes 13-16.

${ }^{88}$ Koscelník 2010, 89.

${ }^{89}$ Novobilský 2008, 67.
} 
type which used smaller projectiles) were able to launch 5,000 stones at the town within 10 hours. This gives 250 projectiles per hour on average, or more than four per minute $!^{90}$ Furthermore, in 1296 troops of Edward I during the siege of the Abbey of Holyrood used three large engines which launched 158 large stones within three days. This gives about 17 stones per day, ${ }^{91}$ which is convergent with the calculations for Castle Karlštejn.

On the basis of the aforementioned numerous examples, both from written sources, iconographic records and archaeological data, it can be said that the appearance of firearms in Central Europe in the late $14^{\text {th }}$ century did not cause an abandonment of throwing engines of various kinds which were in use until that time. The $15^{\text {th }}$ century is therefore a period of simultaneous use of two kinds of projectile throwing devices. Both had their advantages and disadvantages. What spoke in favour of throwing engines was a possibility of shooting both at higher angles (trebuchets) and in flat trajectories (e.g. ballista, great crossbow, onager), while bombards could rather fire in flat trajectories. Throwing engines, especially baroballistic ones, were also more accurate, as there was no recoil during shooting and the structure did not move. Provided that ammunition of the same weight was used, it was possible to bombard selected targets with a high repeatability of hits. Artillery was of course able to compete with throwing engines with regard to that, but in this case a lot depended on master-gunners' experience. Furthermore, trebuchets were much more versatile, as apart from standard stone projectiles they could also launch barrels with excrements or fire, carcasses or non-processed rock material or architectural detail.

Both kinds of artillery were prone to damage, although due to different causes. Barrels of medieval cannons were very susceptible to burst, be it for manufacturing imperfections or unskilled operation. They could also be spiked by defenders during armed sallies. ${ }^{92}$ On the other hand, they were resistant to fire, which could sometimes be successfully used by defenders for destroying siege engines which were chiefly made from wood. The latter were also susceptible to fatigue-related damage of the whole construction or its individual components. ${ }^{93}$

Finally, the throwing engines were definitely cheaper both in performance and later use. Almost exclusively wood was used for their construction, while the production of gun barrels required the employment of specialised craftsmen - founders or smiths. The raw materials themselves - copper, tin or iron - were also expensive, and additional costs were added to the later use (gunpowder, projectiles). ${ }^{94}$ However, artillery had a significant practical advantage. Shooting the steep tracks from the throwing engines made them less effective in demolishing the walls than in the case of the bombards firing straight at the fortifications..$^{95}$

The aforementioned examples seem to demonstrate that the rivalry between throwing engines and artillery was decided upon only at the turn of the $3^{\text {rd }}$ and $4^{\text {th }}$ quarter of the $15^{\text {th }}$ century. Initially in Western Europe, but later on also in Central Europe, cannons became improved by means of adapting them to the use of metal projectiles and by making their operation more effective (the use of ready gunpowder charges). Furthermore, mortars firing at high angles went into use and they could bombard the adversary above the walls. These improvements demonstrated that firearms had a greater development potential than throwing engines. It seems that the latter achieved their peak of development in the Late Middle Ages and further modifications could not significantly improve their parameters. Due to these factors, in the late $15^{\text {th }}$ and in the $16^{\text {th }}$ century mentions of throwing engines were more and more sporadic. Their use became a spectacular event, as it was the case with the aforementioned shooting in Prague in 1505.

\section{Sources}

Archiv... - Archiv český čili Staré písemné památky české i moravské, sebrané z archivů domácích i cízich 14, F. Kalousek (ed.). Praha 1895.

Bartošek z Drahonic, Kronika - Bartošek z Drahonic Kronika. In: I. Hlaváček (ed.), Ze zpráv a kronik doby husitské. Praha 1981, 231-290.

\footnotetext{
${ }^{90}$ DeVries and Smith 2012, 133, 135; Gravett 2018, 62.

${ }^{91}$ Contamine 1999, 112.
}

\footnotetext{
${ }^{92}$ See Strzyż 2014, 238-244.

${ }^{93}$ Szymczak 1979, 33, 42.

${ }^{94}$ Illustrative of the cost of construction and use of medieval artillery see Durdík 1954, 24-25.

${ }^{95}$ Wagner et al. 1956, 80.
} 
Bartossek de Drahonicz, Chronicon - Bartossek de Drahonicz, Chronicon. In: J. Goll (ed.), Fontes Rerum Bohemicarum 5. Praha 1893, 589-628.

Hájek, Kronika ... - Václav Hájek z Libočan, Kronika česká, J. Linka (ed.). Praha 2014.

Jana Długosza Roczniki, ks. 11 - Jana Długosza Roczniki, czyli kroniki sławnego Królestwa Polskiego, ks. 11 (1413-1430), J. Mrukówna (ed.). Warszawa 2009

Jana Długosza Roczniki, ks. 11 i 12 - Jana Długosza Roczniki, czyli kroniki sławnego Królestwa Polskiego, ks. 11 i 12 (1431-1444), J. Mrukówna (ed.). Warszawa 2009.

Joannis de Czarnkow Chronicon... - Joannis de Czarnkow Chronicon Polonorum, J. Szlachtowski (ed.), Monumenta Poloniae Historica 2. Lwów 1872.

Joannis Dlugossii Annales..., liber XI - Joannis Dlugossii Annales seu cronicae incliti Regni Poloniae, liber XI (1413-1430). Warszawa 2000.

Joannis Dlugossii Annales..., liber XI et XII - Joannis Dlugossii Annales seu cronicae incliti Regni Poloniae, liber XI et XII (1431-1444). Warszawa 2001.

Johanns von Posilge, Chronik... - Johanns von Posilge, Officials von Pomesanien, Chronik des Landes Preussen (von 1360 an, fortgesetz bis 1419) zugleich mit des auf Preussens bezüglichen Abschnitten aus der Chronik Detmar's von Lübeck. In: E. von Strehlke (ed.), Scriptores Rerum Prussicarum 3. Leipzig 1866.

Kriegsbuch, Philipp Mönch, c. 1496, Heidelberg, Codex Palatinus germanicus 126.

Księgi Hetmańskie... - Stanisław Sarnicki, Księgi Hetmańskie z dziejów rycerskich wszystkich wieków zebrane i praktyka abo experientia hetmanów Najjaśniejszego Zygmunta Starego Króla Polskiego, a także Cesarza Karla V $i$ Solimana Tureckiego dwu panów walecznych za naszego wieku objaśnione ku ćwiczeniu młodych ludzi nacyjej naszej Polskiej pod tytutem, M. Ferenc (ed.). Kraków 2015.

Kyeser, Bellifortis - Konrad Kyeser, Bellifortis. Umschrift und Übersetzung Götz Quarg, vol. 1-2. Düsseldorf 1967. Laurentii de Brzezowa Historia... - Laurentii de Brzezowa Historia Hussitica. In: J. Goll (ed.), Fontes Rerum Bohemicarum 5. Praha 1893, 327-534.

Listář... - Listáŕ a listinár Oldřicha z Rožmberka IV: 1449-1462, B. Rynešová, J. Pelikán (eds.). Praha 1954.

Staré letopisy... - Staré letopisy české z rukopisu Křǐ̌ovnického, F. Šimek, M. Kaňák (eds.). Praha 1959.

Vavřinec z Březové, Husitská... - Vavřinec z Březové, Husitská kronika, F. Heřmanský, M. Bláhová (eds.). Praha 1979.

Vegetius, De re militari - Vegetius Renatus Flavius, De re militari, c. 1512, http://daten.digitale-sammlungen. $\mathrm{de} / \sim \mathrm{db} / 0001 / \mathrm{bsb} 00011426 /$ images/index.html?id=00011426\&fip=eayayztsewqeayaxssdasyztsqrseayax$\mathrm{s} \& \mathrm{no}=\&$ seite $=1$. Available on-line: 15.04 .2020 .

Ze starých... - Ze starých letopisů českých, J. Porák, J. Kašpar (eds.). Praha 1980.

Život... - Život Jana z Jenšteina, arcybiskupa Pražského. In: J. Emler (ed.), Fontes Rerum Bohemicarum 1. Praha 1873.

\section{Bibliography}

Burian V. 1966a. Kartouzka v Dolanech - moravský protějšek hradu Siónu. "Střední Morava" 1, 5-18.

Burian V. 1966b. Předběžná zpráva o historickoarcheologickém výzkumu Kartouzky v Dolanech 1964-1965. "Zprávy Vlastivědného ústavu v Olomouci" 128, 9-15.

Burian V. 1985. Projektily těžkých palných a vrhacích zbraní z Tepence a Dolan. "Zprávy Krajského vlastivědného musea v Olomouci” 234, 20-25.

Chevedden P. E. 1999. Artillery in Late Antiquity: Prelude to the Middle Ages. In: I. A. Corfis, M. Wolfe (eds.), The Medieval City under Siege. Suffolk, 131-173.

Contamine P. 1999. Wojna w średniowieczu, transl. M. Czajka. Warszawa.

DeVries K., Smith R. D. 2012. Medieval Military Technology, $2^{\text {nd }}$ editon. Toronto.

Drobná Z. 1953. Husitský polní tábor u Kunratic. "Historie a vojenství" 2, 197-200.

Durdík J. 1954. Husitské vojenství. Praha.

Durdík T. 1981. Povrchový průzkum zaniklého středověkého sídlištního komplexu Stará Dubá. "Sborník vlastivědných prací z Podblanicka" 21, 141-168.

Durdík T. 1982. Jižni předsunutá bašta hradu Českého Šternberka. "Sborník vlastivědných prací z Podblanicka" $22,127-155$.

Durdík T. 2009. Ilustrovaná encyklopedie českých hradů, $3^{\text {rd }}$ edition. Praha.

Durdík T. 2011. Obleženi hradu Zlenice. In: O. Ławrynowicz, J. Maik, P. A. Nowakowski (eds.), Non sensistis gladios. Studia ofiarowane Marianowi Gtoskowi w 70. rocznicę urodzin. Łódź, 565-573. 
Dyachkov S. 2011. The 15 th Century Brigandine of a Crossbowman from the Genoese fortress of Cembalo. "Acta Militaria Mediaevalia" 7, 175-190.

Frankenberger O. 1960. Husitské válečnictvi po Lipanech. Praha.

Frolík J. 2002. Nálezy z obléhání hradu Lichnice v letech 1428-1429. "Castellologica Bohemica" 8, 399-408.

Głosek M. 1990. Artyleria przedogniowa. In: A. Nadolski (ed.), Uzbrojenie w Polsce średniowiecznej 1350-1450. Łódź, 153-155.

Gravett Ch. 2018. Średniowieczna sztuka oblężnicza. Oświęcim.

Hložek J., Menšík P. 2017. Hrad Věžka a jeho odkryv v rekonstruovaných fototabulkách Václava Uchytila. "Castellologica bohemica" 17, 315-412.

Janská E. 1963. Archeologický výzkum hradu Sión. “Archeologické rozhledy” 15(2), 220-247.

Janská E. 1965. Hrad Jana Roháče z Dubé Sión. "Sborník oblastního muzea v Kutné Hoře”, řada A - historická 6/7, 5-72. Jurga R. M. 1995. Machiny wojenne. Kraków, Warszawa.

Klučina P. 2004. Zbroj a zbraně. Evropa 6.-17. století. Praha, Litomyšl.

Koscelník P. 2010. Obléháni hradu Karlštejn roku 1422. In: P. Krištuf (ed.), Archeologická studia. Sborník z 1. archeologické studentské konference Katedry archeologie FF ZČU v Plzni. Plzeň, 87-98.

Koscelník P., Juk1 J. 2016. Obléhaní hradu Perštejn roku 1451. "Castellologica bohemica" 13, 267-280.

Koscelník P., Kypta J., Savková J. 2013. Dobývání hradu Siónu roku 1437. Povrchový průzkum palebných postaveni obléhateli̊. "Archeologické rozhledy" 65(3), 574-598.

Kypta J., Laval F., Marounek J., Neustupný Z. 2016. Terénní stopy trojího obleženi hradu Zbořeného Kostelce (1449, 1450, 1467). "Průzkumy památek" 23(1), 95-116.

Kypta J., Podliska J. 2014. Tábor obléhatelů na předpoli Nového hradu u Kunratic (1420/1421). Povrchový průzkum a srovnání s analogickými lokalitami. "Archeologické rozhledy" 66(4), 609-632.

Kypta J., Richterová J. 2003. Tábor obléhateli u hradu Velkého Vřeštova. "Hláska" 14, 37-40.

Kypta J., Richterová J. 2004. Tábor obléhatelů z doby husitských válek u Bechyně. In: J. Anderle (ed.), Dějiny staveb, Sbornik př̀spěvků z konference Dëjiny staveb 2002. Plzeň, 177-192.

Mazáčková J. 2013. Rokštejn Castle (Czech Republic): Archaeological Evidence of Military Activites. In: L. Marek (ed.), Weapons Bring Peace? Warfware in Medieval and Early Modern Europe. Wratislavia Antiqua 18. Wrocław, 255-289.

Meduna P. 1984. Pozůstatky středověké militární činnosti u hradu Kostelce nad Sázavou. "Sborník vlastivědných prací z Podblanicka” 25, 119-128.

Meduna P. 1994. Povrchový průzkum komplexu obléhacích prací u Konopiště z let 1467-1468. "Castellologica bohemica" 4, 243-250.

Menclová D. 1972. České hrady 2. Praha.

Měř́nský Z. 1980. Morava za husitských válek ve světle archeologických nalezů a výzkumů. "Archaeologia historica" 5, 31-68.

Měřínský Z., Plaček M. 1991. Terénni pozůstatky fortifikačnich systémů v předpoli hradu Cornštejna (k. ú. Bítov, okr. Znojmo). "Castellologica bohemica" 2, 161-176.

Novobilský M. 2008. Obléhání hradu Lopaty. Rekonstrukce obléhání hradu z roku 1432-1433. Plzeň.

Novotný B. 1970. Nálezy ze zaniklého hradu Tepence (okr. Olomouc). "Přehled výzkumů" 1968, 63-64.

Nowak T. M. 1965. Z dziejów techniki wojennej w dawnej Polsce. Warszawa.

Procházka R. 1982. K některým problémům dějin Boskovic a Boskovicka v době předhusitské a husitské. "Sborník Okresního muzea v Blansku" 13-14 (1981-1982), 39-50.

Schmidtchen V. 2001. Mittelalterliche Kriegstechnik zwischen Tradition und Innovation. In: U. von Lindgren (ed.), Europäische Technik im Mittelalter 800 bis 1400. Tradition und Innovation. Ein Handbuch. Berlin, 305-316.

Sedláček A. 1889. Hrady, zámky a tvrze království českého 6, Podbrdsko. Praha.

Sedláček A. 1893. Hrady, zámky a tvrze královstvi českého 9, Domažlicko a Klatovsko. Praha.

Sedláček A. 1900. Hrady, zámky a tvrze království českého 12, Čáslavsko. Praha.

Serdon V. 2005. Armes du diable. Arcs et arbalètes au Moyen Âge. Rennes.

Sikorski J. 1991. Polskie piśmiennictwo wojskowe od XV do XIX wieku. Warszawa.

Strzyż P. 2014. Broń palna w Europie Środkowej w XIV-XV w. Łódź.

Sýkora M. 2015. Poloha „Na Baště “ a její vztah ke hradu Cornštejn. Unpublished manuscript kept at Archive of the University of Plzeň. Plzeň.

Szymczak J. 1979. Sposoby zdobywania i obrony grodów w Polsce w okresie rozbicia dzielnicowego. "Studia i Materiały do Historii Wojskowości” 22, 3-63. 
Szymczak J. 2004. Początki broni palnej w Polsce (1383-1533). Łódź.

Szymczak J. 2005. Siege Artillery in Poland in the Fourteenth and the Fifteenth Centuries. "Fasciculi Archaeologiae Historicae" 16-17 (2003-2004), 111-120.

Teplý J. 2007. Obleženi hradu Lichnice 1428-1429. Dnešní stav po obléhacím okruhu. In: M. Drda, Z. Vybíral (eds.), Jan Žižka z Trocnova a husitské vojenství v evropských dějinách. VI. Mezinárodni husitolologické symposium, Tábor 12.-14. řijna 2004. Husitský Tábor - Suplementum 3. Tábor, 463-489.

Tymonová M. 2002. Středověký hrad Tepenec u Jivové a jeho fortifikační systém. "Archaeologia historica" 27, 215-228.

Wagner E., Drobná Z., Durdík J. 1956. Kroje, zbroj a zbraně doby husitské a předhusitské (1350-1450). Praha.

Žákovský P., Schenk Z. 2017. Středověké a raně novověké zbraně Přerovska. Zbraně a zbroj od kolapsu Velké Moravy do konce třicetileté války. Přerov, Brno. 